\title{
Homesteading Rock: A Defense of Free Access under the General Mining Law of 1872
}

Andrew P. Morriss

Texas A\&M University School of Law, amorriss@law.tamu.edu

Roger E. Meiners

Andrew Dorchak

Follow this and additional works at: https://scholarship.law.tamu.edu/facscholar

Part of the Law Commons

\section{Recommended Citation}

Andrew P. Morriss, Roger E. Meiners \& Andrew Dorchak, Homesteading Rock: A Defense of Free Access under the General Mining Law of 1872, 34 Envtl. L. 745 (2004).

Available at: https://scholarship.law.tamu.edu/facscholar/71

This Article is brought to you for free and open access by Texas A\&M Law Scholarship. It has been accepted for inclusion in Faculty Scholarship by an authorized administrator of Texas A\&M Law Scholarship. For more information, please contact aretteen@law.tamu.edu. 


\title{
ARTICLE
}

\section{HOMESTEADING ROCK: \\ A DEFENSE OF FREE ACCESS UNDER THE GENERAL MINING LAW OF 1872}

\author{
BY \\ ANDREW P. MORRISS, ROGER E. MEINERS, AND ANDREW DORCHAK
}

\begin{abstract}
The Mining Law of 1872 is one of the most reviled federal land laws, regularly drawing attacks as anachronistic, corporate welfare, a relic of pioneer days, and a source of major environmental problems. Born out of the experience of the nineteenth century mineral rushes, the Mining Law allows individuals to privatize both the surface estate and the mineral rights to public land containing minerals (with some exceptions) without requiring a significant payment to the public treasury for the land. This "giveaway" aspect of the law draws the loudest protests. The authors argue that it is inappropriate to measure the net value of mineral rights privatized by the gross revenue generated by the sale of extracted minerals. Only if the exploration and production costs are also considered can the net value be
\end{abstract}

\footnotetext{
"(C) Andrew P. Morriss, 2004. Galen J. Roush Professor of Business Law and Regulation and Director, Center for Business Law \& Regulation, Case Western Reserve University School of Law; Senior Associate, Property and Environment Research Center (PERC), Bozeman, Montana; Ph.D. (Economics) 1994, Massachusetts Institute of Technology; J.D., M. Pub. Aff. 1984, University of Texas at Austin; A.B. 1981, Princeton University. Support from the Mining and Metallurgical Society of America and from PERC is gratefully acknowledged. Comments from Jonathan $H$. Adler and Terry L. Anderson improved the paper; of course, we remain responsible for all errors.

-(C) Roger E. Meiners, 2004. Professor of Economics and Law, University of Texas at Arlington; Senior Associate, PERC, Bozeman, Montana; J.D. 1978, University of Miami; Ph.D. (Economics) 1977, Virginia Polytechnical Institute; M.A. 1972, University of Arizona; B.A. 1970, Washington State University.

- (C) Andrew Dorchak, 2004. Head of Reference and Foreign/International Law Specialist, Case Western Reserve University School of Law; M.L.S. 1994, Kent State University; Honors B.A. 1988, Xavier University.
} 
determined. Once these costs are considered, the net value of mineral rights privatized under the Mining Law is relatively small.

In this Article, the authors argue that the attacks on the Mining Law misunderstand the statute's institutional incentives. The mining industry is a heavily capital-intensive industry whose activities involve significant risks and long lead-times. As a result, mining firms are extremely vulnerable to expropriation, as their experience in much of the rest of the world amply demonstrates.

The Mining Law creates an institutional structure that reduces the expropriation problem and forces owners of mineral lands to address the opportunity costs of their land-use choices by effectively "selling" the land in exchange for the production of information about the mineral resources under it rather than for money.

$B y$ providing mineral rights owners with the option to receive the surface estate as well as the mineral rights for a nominal fee, the Mining Law helps deter opportunistic behavior by the government. Since expropriating a mineral rights owner who also holds the surface estate would reduce the value of all land titles, the Mining Law raises the cost of expropriation.

Full title also solves incentive problems that exist where rights holders have more limited titles. Ownership of both surface and mineral estates gives the property owner the incentive to maximize the joint value of the two estates. If the mineral rights owner does not hold the surface rights as well, activities which are destructive of the surface estate are more likely to occur.

Providing a straightforward, administrative system for privatizing mineral rights that does not allow the agency charged with privatization discretionary authority minimizes the opportunities for corruption as well. Given the prevalence of corruption in the mining industry elsewhere in the world, this is an important advantage of the Mining Law's nondiscretionary approach.

There are competing demands for lands containing mineral resources. A potential mine site may also be an ideal habitat for wildlife or a picture-perfect ski run. The Mining Law's privatization of both surface and mineral estates solves the conflicting use problem by giving the owner of the mineral estate the surface rights as well. If mining will reduce the surface estate's value, the mineral rights owner will then suffer the loss. Seen in this light, the nonmining uses of land privatized under the law (a frequent complaint of critics) actually demonstrates the success of the law at resolving these conflicts. Moreover, because the Mining Law does not require mining on land privatized under it, interest groups favoring preservation can use it to preserve the land.

Finally, the Article addresses the claim that mining produces harm to neighboring lands. The authors show that only environmental spillovers unique to mining justify mining-specific restrictions on property use. 
The Article also tests the incentive theory developed against the history of modifications of the Mining Law (resource and land withdrawals), the quite different practice of the states with respect to their public lands, and by comparing the Mining Law to the other major nineteenth century land disposal laws, the Homestead Laws.

Homesteading has been criticized for overly rapid privatization of land and for causing rent-dissipating races for property rights. The authors argue that the Mining Law avoids the problems of the Homestead Laws because the "race" it induces is a race for useful knowledge, not a race won by enduring hardship. The Mining Law also does not require that the land privatized be brought into production as the Homestead Laws did. The resource withdrawals (fuel and "common" minerals) can be explained by a combination of technical characteristics (e.g., the pool nature of oil and gas reserves) and interest group politics (military interest in controlling domestic oil supplies). Federal land withdrawals from Mining Law coverage also do not undercut the incentive analysis of the Mining Law, as these withdrawals are of land dedicated to particular uses by the federal government and acquired lands where allowing privatization raises serious agency problems. States' failure to adopt a similar method for privatizing their mineral lands is also explained through a comparative analysis of state and federal agency costs.

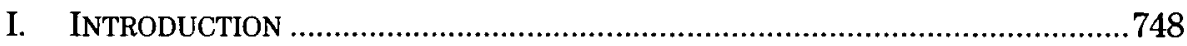

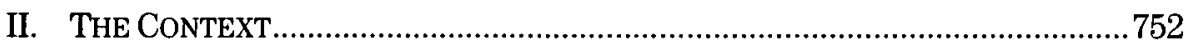

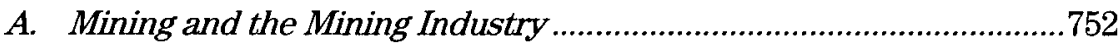

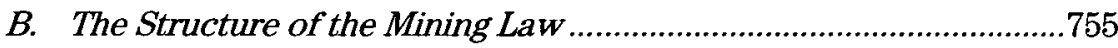

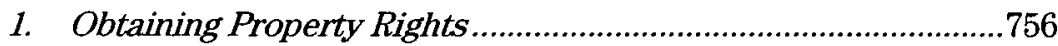

2. The Evidence on the Giveaway Claim.....................................758

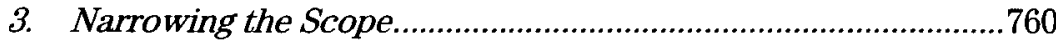

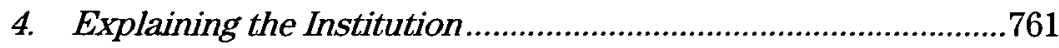

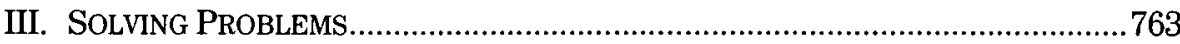

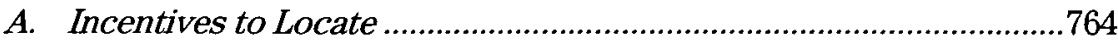



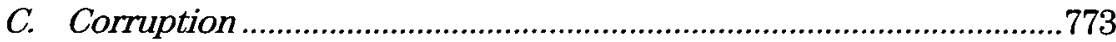

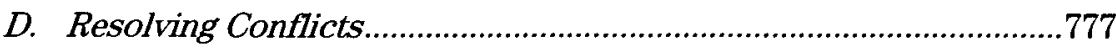



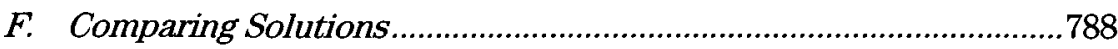

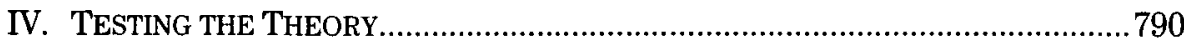

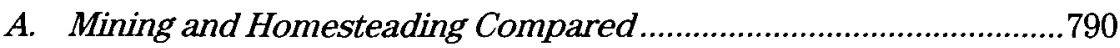

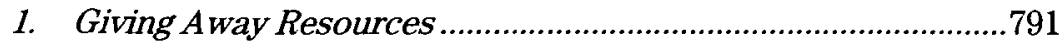

2. Was Homesteading Rent-Seeking? ...........................................792

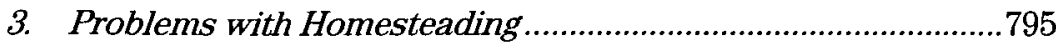

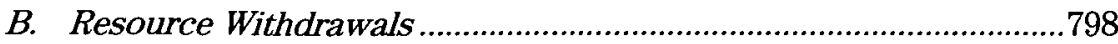

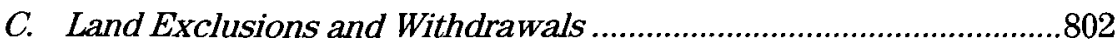

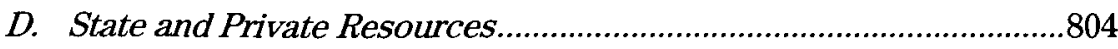




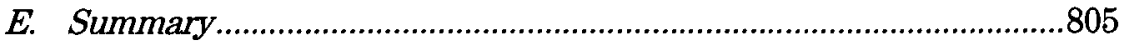

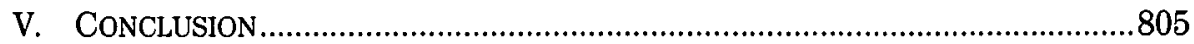

\section{INTRODUCTION}

The discovery of gold in 1848 at Sutter's Mill in California changed American mining law forever. ${ }^{1}$ Within weeks, thousands poured into the area seeking riches. ${ }^{2}$ With no official sanction, and in a region with no official civilian government, prospectors staked claims and searched for gold. When they found it, they took it for their own. ${ }^{3}$ Throngs followed over the next decades as the gold rush spread from California to Nevada, the Dakotas, Montana, Colorado, Alaska, and wherever gold or other valuable minerals could be found. When Congress finally addressed the miners' claims, it had little choice but to ratify the miners' methods. ${ }^{4}$ The Lode Law of $1866,{ }^{5}$ the 1870 Placer Act, ${ }^{6}$ and, most importantly, the Mining Law of 1872 (Mining Law $)^{7}$ recognized claims based on individual actions appropriating the minerals from federal lands. ${ }^{8}$ Despite high-level attacks on this system ${ }^{9}$ and a gradual narrowing of the scope of the minerals appropriable under the

1 Bancroft G. Davis, Fifty Years of Mining Law, 50 HARv. L. REv. 897, 897 (1937) ("The mining law of the United States owes its origin to the discovery of gold in California in 1848.").

2 See Andrew P. Morriss, Miners, Vigilantes \& Cattlemen: Overcoming Free Rider Problems in the Private Provision of Law, 33 LAND \& WATER L. REv. 581, 593-616 (1998) (discussing mining law's origins in the California gold rush, comparing California's gold rush to the later Black Hills gold rush of the 1870s).

3 See William E. Colby, Mining Law in Recent Years, 33 CAL. L. REv. 368, 370 (1945) ("Congress had not legislated, so that it was impossible to legally acquire title to [land in California]."); see generally JOHN UMBECK, A THEORY OF PROPERTY RIGHTS, WITH APPLICATION TO THE CALIFORNIA GOLD RUSH 79-98 (1981) (describing early gold mining contracts and the emergence of property rights in California after the discovery of gold); John Umbeck, $A$ Theory of Contract Choice and the California Gold Rush, 20 J.L. \& ECON. 421, 432-37 (1977) (describing "sharing" and "land allotment" contracts that developed after gold was discovered in California).

4 See, e.g., Mining Laws of 1872 and 1989: Hearing on S. 1126 Before the Subcomm. on Mineral Res. Dev. and Prod. of the Senate Comm. on Energy and Natural Res., 101st Cong. 35 [hereinafter 1990 Senate Hearings] (statement of Dr. Sandra L. Blackstone, Consultant) (attributing early mining law to federal government's inability to enforce rules in the West due to lack of funds and troops); JOHN D. LESHY, THE MINING LAW: A STUDY IN PERPETUAL MOTION 14 (1987) ("The basic outcome [of the 1860s debate over mining law]-legal ratification of what had become an established pattern of mineral exploitation-was never seriously in doubt.").

5 An Act of July 26, 1866, ch. 262, 14 Stat. 251 (repealed 1872).

6 An Act of July 9, 1870, ch. 235, 16 Stat. 217.

7 General Mining Act of 1872 , ch. 152,17 Stat. 91 (codified as amended at 30 U.S.C. $\S \S 22-$ $24,26-30,33-35,37,39-43,47(2000)$ ).

8 Earl M. Hill, A Brief History of the Nevada Law of Mining, NEv. LAw., Oct. 1999, at 12, 1314.

9 When pressing for change in the Mining Law of 1872, Secretary of Interior Bruce Babbitt said, "This process has gone from distasteful to obscene .... Let's call this exactly what it is: corporate welfare." News Release, Department of the Interior, Christmastime in Washington: Babbitt Forced to Give $\$ 3$ Billion "Gift" to Mining Company (Dec. 1, 1995), 1995 WL 705352. 
Mining Law and the lands available for appropriation, ${ }^{10}$ more than a century and a half later ${ }^{11}$ the basic system remains intact for hardrock minerals. ${ }^{12}$

Mining and the Mining Law are regularly the subject of heavy criticism by a variety of interest groups. ${ }^{13}$ The Mining Law is derided as "an anachronism,"14 "outdated since its inception,"15 "a "tawdry process,"'16 "not only grossly outdated, but in most meaningful ways, inimical to today's needs and values,"17 "a disgrace to the Government of the United States," "gargantuan prehistoric fire breathing dragon,"19 "one of the last remaining American dinosaurs of the old public resource giveaways," ${ }^{20}$ "passed in the spirit of Manifest Destiny," ${ }^{21}$ a "relic of pioneer days," ${ }^{22}$ and "obsolete and antiquated. ${ }^{23}$ It is "corporate welfare"24 and a gift of public resources to

10 See Mineral Leasing Act of $1920 \S 1,30$ U.S.C. $\S 181$ (2000) (removing oil, gas, oil shale, phosphates, and sodium); Materials Act of $1947 \S 1,30$ U.S.C. 601 (2000) (removing common variety minerals, e.g., sand, stone, and gravel).

11 We date the system to 1849 although the Mining Law itself dates only to 1872.

12 "Hardrock mining involves uncovering and extracting non-fuel metal and mineral deposits of solid ores or eroded deposits in streambeds. Eleven common minerals mined are copper, gold, iron ore, lead, molybdenum, phosphate rock, platinum, potash, silver, uranium, and zinc." OfFice of Wastewater MANagement, U.S. ENVTL. PROT. AGENCY, HaRdrock Mining OVERVIEW, at http://www.epa.gov/npdes/pubs/overview.htm (last visited July 7, 2004).

13 James F. Cress \& Cecilia G. Dalupan, Sustainable Development and Mining Law: Is a "Mine Veto" Needed?, 17 NAT. RESOURCES \& ENV'T 164, 164 (2003) ("Mining is one of the most controversial human activities.").

14 Christine Knight, Comment, A Regulatory Minefield: Can the Department of Interior Say "No" to A Hardrock Mine?, 73 U. CoLO. L. REv. 619, 621 (2002). Even mining law supporters seem at times to concede to the assertion that the Mining Law is a relic of the past. For example, Senator James McClure of Idaho, who opposed royalties and other features of "reform" efforts, opened his remarks at a hearing on a bill to impose royalties by stating that the Mining Law's "primary goal was to promote mineral development," implicitly conceding that it does not meet the modern multiple use approach. 1990 Senate Hearings, supra note 4, at 3. Critics argue that the law "was created during the heyday of the wholesale disposal of the western public domain in order to facilitate America's 'Manifest Destiny' to rule the continent from sea to shining sea, an objective today that has long since been accomplished." David Alberswerth, The Mining Law: Time to Pull the Plug, in 1990 Senate Hearings, supra note 4, at $253,256$.

15 Robbie D. Harrington, Note: South Dakota Mining Association v. Lawrence County: Kleppe and Granite Rock Collide, 3 Great PlaINS NAT. REsoURCes J. 87, 87 (1998).

16 Tom Kenworthy, $A \$ 1$ Billion Return for $\$ 275$, WASH. PosT, Sept. 7, 1995, at A17 (quoting then Secretary of the Interior Bruce Babbitt).

17 Knight, supra note 14 , at 626.

18 Legislation to Revise the Public Land Laws: Hearings on S. 921, S. 2401, S. 2450, and S. 2542 Before the Senate Comm. on Interior and Insular Affairs, 92d Cong. 232 (1971) [hereinafter 1971 Senate Hearings] (statement of the Mr. Charles H. Callison, Executive Vice President, National Audubon Society).

19 Mining Law Reform: Hearings on H.R. 5831 and H.R. 9292 Before the Subcomm. on Mines and Mining of the House Comm. on Interior and Insular Affairs, 95th Cong. 224 (1977) (statement of Ms. Raye-Page, Wilderness Society).

20 Mineral Policy Ctr., The last American Dinosaur... The 1872 Mining LaW 1 (n.d.), available at http://www.earthworksaction.org/ewa/pubs/MPCfs_LastAmericanDinosaur.pdf.

21 Nicole Rinke, The Crown Jewel Mining Decision: Recognizing the Mining Law's Inherent Limits, 27 ECOLOGY L.Q. 819, 820-21 (2000).

22 Alberswerth, supra note 14, at 253.

231971 Senate Hearings, supra note 18, at 200 (statement of Thomas L. Kimball, Executive Director, Nat'l Wildlife Federation). 
private interests; ${ }^{25}$ it allows "[u]ncontrolled mining[,] . . a menace which can strike almost anywhere, often in the midst of the most environmentally valuable and vulnerable places," 26 and lets "huge mining conglomerates... wreak environmental havoc on public lands." ${ }^{27}$ It "plunders taxpayers"28 and is "the largest ongoing scam in American history." ${ }^{29}$ It allows "foreign-owned corporations from ten countries [to] have collectively gained control of metals beneath one of every five acres of claimed lands in the United States." ${ }^{30}$ Even a policy analysis from the libertarian Cato Institute managed only "two cheers" for the law, concluding that it would have deserved "a third cheer were it a more robust engine of unbiased privatization." ${ }^{31}$

In the face of this onslaught, even some of the strongest industry supporters in Congress, such as Democratic South Dakotan Senator Thomas Daschle, whose state has important mining interests, ${ }^{32}$ called for the industry "to face the inevitability of reform" and work with critics "to guide and perfect" the law. ${ }^{33}$ The Mining Law must change, critics argue, to recognize modern environmental concerns and generate revenue for the federal government. ${ }^{34}$ Nonetheless, reform has not come, in part because the threat to the free-access principle from change unites the mining industry

24 Brad Knickerbocker, Call to Ban Mining Pits New West Against Old, Christlan SCI. MONITOR, Feb. 5, 1999, at 3 (quoting Jill Lancelot, Taxpayers for Common Sense legislative director).

25 Daphne Werth, Comment, Where Regulation and Property Rights Collide: Reforming the Hardrock Act of 1872, 65 U. CoLo. L. REv. 427, 443 (1994) ("[M]ammoth corporations control the vast majority of the mining industry. These corporations drive opposition to the mining law reforms because they fear the loss of the generous government subsidies in place for the past one-hundred and twenty-one years."); see also, MARC HUMPHRIES, CONG. RESEARCH SERVICE, ISSUE BRIEF 89130, MINING ON FEDERAL LANDS 2 (2003) ("These per-acre fees were substantial when the Mining Law was enacted-claimed land and minerals now far exceeds these amounts in value."); GENERAL ACCOUNTING OFFICE, REPORT NO. RCED-89-72, FEDERAL LAND MANAGEMENT: THE MINING LAW OF 1872 NEEDS REVISION 41 (1989) ("The federal government stands to lose between $\$ 14.4$ million and $\$ 47.1$ million if the 12 pending applications included in our review are patented, and tens of millions of dollars more if the patent provision of the Mining Law of 1872 is not amended.").

261971 Senate Hearings, supra note 18, at 215 (statement of Mr. J. Michael McCloskey, Conservation Director, Sierra Club).

27 Knight, supra note 14, at 621.

28 Brad Knickerbocker, Senate Drills Into Hardrock Mining, CHRISTIAN SCI. MONITOR, Mar. 30,1995 , at 4 (quoting the National Taxpayers Union).

29 Id. (quoting Senator Dale Bumpers).

30 ENVIRONMENTAL WORKING GROUP, Mining IN THE UNITED STATES $\S 1$, http://www.ewg.org/mining/report/index.php?stab=US\&chapter=1 (last visited July 10, 2004).

31 Richard Gordon \& Peter Vandoren, Cato Policy analysis No. 300, Two CheERs for THE 1872 MINING LAW, at para. 15 (1998), available at http://www.cato.org/pubs/pas/pa-300.html.

32 See, e.g., Robert Pear, Mining Company Is Given Protection, N.Y. Times, January 3, 2002, at A20 (noting Daschle's ties to the mining industry).

331990 Senate Hearings, supra note 4, at 9.

34 See Charles Davis, American Federal Lands and Environmental Politics: Politics as Usual or a New Ball Game?, 19 PUB. LAND \& RESOURCES L. REV. 5, 11 (1998) ("[P]ro-environmental members of Congress[] pushed a number of policy initiatives designed to challenge the view that extractive users [of public lands] had a superior claim to resource use."). 
and western interests in opposition to beginning a process they cannot control. ${ }^{35}$

The Mining Law appears to be an easy target. As just noted, the critics argue that it privileges an environmentally risky activity conducted by a small number of companies over recreation, preservation, and other interests popular with large numbers of American voters. ${ }^{36}$ The mining companies, some foreign owned, are said to extract valuable resources from public land without paying substantial sums that ought to belong to the federal treasury. ${ }^{37}$ Despite the populist appeal of their arguments and decades of efforts, however, critics of the Mining Law have not yet succeeded in persuading Congress to change any of the basic principles articulated in the 1872 law with respect to hardrock minerals. ${ }^{38}$

In this Article we argue that the critics' failure is a good thing. The critics are wrong about the structure and impact of the Mining Law. It is not a relic of discarded nineteenth century robber-baron attitudes ${ }^{39}$ toward the land and minerals. Rather what former Interior Secretary Donald Hodel called "the heart and soul" of the Mining Law ${ }^{40}$ - the principle of selfinitiated free access to mineral resources and the provision of full title to both mineral and surface estates for minimal transfer fees-provides a rational basis for allocating resources in a principled manner that solves critical information and incentive problems inherent in public ownership of resources. ${ }^{41}$ Most "reform" efforts aimed at the Mining Law take the wrong approach, ${ }^{42}$ attacking free access and focusing on generating revenue from royalties ${ }^{43}$ rather than on removing doctrinal technicalities that hinder free access. We contend that, far from needing replacement, the Mining Law offers an important model for governments looking for the means to

35 See LeSHY, supra note 4 , at $347-48$ (noting that the stalemate between those opposed to free access and those in favor has "petrified the legislative process").

36 Davis, supra note 34 , at 5 ("These laws provide benefits to a relatively small number of extractive user groups while spreading the costs to U.S. taxpayers writ large.").

37 Tom Kenworthy, A Court-Ordered "Gold Heist", WASH. PosT, May 17, 1995, at A5 (accepting $\$ 9,765$ from a Canadian mining company for a patent on 1,800 acres of federal land, then Secretary of the Interior Bruce Babbitt said it was "the biggest gold heist since the days of Butch Cassidy").

38 See LESHY, supra note 4, at 287-312 (giving history of "reform" efforts); Robert J. Uram, Prospects for Mining Law Reform, 12 NAT. RESOURCEs \& ENV'T 191, 191-95 (1998) (recounting history of attempts to amend the Mining Law).

39 Sharon Begley \& Daniel Glick, The Last Great Giveaway, NEwSwEEK, May 30, 1994, at 66 (stating that the Mining Law "sounds like the sort of robberbaron capitalism that ran rampant through the 19th century").

40 Donald P. Hodel, Introduction to THE Mining LAW of 1872: A LEGAL AND Historical ANALYSIS, at xi (1989).

41 Note that we do not argue that the authors of the Mining Law consciously designed it to accomplish those ends, but rather that they stumbled upon an institutional arrangement that does and so is worth preserving.

42 These attempts are "wrong" if the goal is truly to improve the Mining Law, rather than simply to attack the mining industry with any available policy tool. We suspect that many critics of the Mining Law would welcome a total cessation of mining even if they do not (yet) directly seek such an outcome.

43 It is not clear that royalties are the revenue-maximizing policy, since royalties will reduce the taxable income generated from mining activity by reducing the level of mining activity. 
privatize public property where the value of the property is unknown. Not just mineral rights but assets such as radio spectrum frequencies are problematic as publicly owned resources. ${ }^{44}$ The Mining Law can serve as a model for privatization of such resources both here and abroad.

In Part II we describe the structure of the mining industry and how the Mining Law functions. In Part III we discuss the problems surrounding public domain resources and explain how the Mining Law responds to them. In Part IV we test our theory by examining the allocation of mineral resources among the various mining law regimes in the United States. Part V concludes with a discussion of the future of the Mining Law in light of the insights gained in this Article.

\section{THE CONTEXT}

To understand the debate over the Mining Law, it is necessary to know something of the structure of the mining industry and how the law operates. In this section we briefly review these matters, highlighting the features which affect our analysis of the Mining Law. We then survey the explanations for the Mining Law's persistence and offer our own theory.

\section{A. Mining and the Mining Industry}

There are three key characteristics of the modern U.S. mining industry. The first is that its economic structure creates vulnerability to political risks. Hardrock mining ${ }^{45}$ is a generally capital-intensive industry, in which large quantities of low-grade ore must be extracted from the earth and processed to produce a mixture of useable minerals. ${ }^{46}$ Mining's capital intensity and fixed location renders it vulnerable to expropriation; once a mine is developed it cannot be moved. This vulnerability made possible the wave of nationalizations and controlling legislation adopted in developing countries in the $1960 \mathrm{~s}$ and $1970 \mathrm{~s} .{ }^{47}$ Highlighting the importance of strong property

44 See Ronald Coase, The Federal Communications Commission, 2 J.L. \& EcoN. 1, 17-24 (1959) (proposing property rights based system of allocation of spectrum rights).

45 In using the term "hardrock" we follow the National Research Council. See NAT'L RESEARCH COUNCIL, HARDROCK MINING ON FEDERAL LANDS 12-13 (1999) (explaining use of "hardrock" rather than the legal term "locatable" because the latter is not widely used in the technical literature).

46 HUMPHRIES, supra note 25, at 4 ("Modern hardrock mineral exploration requires a continuous effort using vast tracts of land and sophisticated and expensive technology.");


No. 1, AN INTRODUCTION TO GEOLOGY AND HARDROCK MiNING, at ch. 2, pt. A (1998), available at http://www.rmmlf.org/SciTech/Lacy/lacy.htm (noting capital intensity of mining operations); Rinke, supra note 21 , at 825 ("The high-grade mines of yesterday have long since been mined and have given way to low-grade deposits of significantly inferior quality.").

47 See generally Abba Kolo \& Thomas W. Wälde, Renegotiation and Contract Adaptation in International Investment Projects-Applicable Legal Principles and Industry Practices, $1 \mathrm{~J}$. WORLD INVESTMENT 5 (2000); Detlev F. Vagts, Coercion and Foreign Investment Rearrangements, 72 AM. J. INT'L L. 17, 18-19 (1978) (noting cases of expropriation in the $1960 \mathrm{~s}$ and 70s). 
rights when such vulnerabilities exist, these expropriations led mining companies to withdraw from those countries and concentrate their efforts on the United States and other countries with more secure property rights. ${ }^{48}$

Although no one thinks it is likely that any government in the United States will nationalize mines tomorrow, mining in the United States remains vulnerable to "regulatory expropriation." ${ }^{49}$ Just as property owners can lose their property rights through the imposition of severe regulatory burdens as well as outright seizures, so businesses are vulnerable to having the value of their assets used to prevent escape from regulatory burdens (at least in the short run). The more capital-intensive an industry, the more valuable assets are at stake.

This effect is more serious for mining than other capital-intensive industries because hardrock mining today is a regional industry: Arizona, California, Montana, Nevada, and Wyoming have the most mining activity. About $45 \%$ of claims at the end of fiscal year 2000 were in Nevada and almost $35 \%$ more were in the other four states. ${ }^{50}$ Since most states have little or no interest in the mining industry, and since mineral resources are largely on federal land, states without mining interests form a majority coalition in favor of converting those resources into a form which potentially benefits their citizens at the expense of mining state citizens. Only the protection provided minority interests by the structure of the U.S. Senate has prevented such a resource transfer. ${ }^{51}$

48 James OtTo \& John CORdes, The REgulation of Mineral EnterPRises: A Global Perspective on ECONOMICS, LAW AND POLICY 1-48 (2002).

49 The National Research Council concluded that regulation of mining already has reached the level at which "it is only the larger, more established firms that can afford to make the investment in time, extensive data collection, complex analyses, and expensive environmental protection measures that the state and federal regulations currently require." NAT'L RESEARCH Councll, supra note 45 , at 33 .

50 HUMPHRIES, supra note 25 , at 2-3.

51 See Andrew P. Morriss, Roger E. Meiners \& Andrew Dorchak, Between a Hard Rock and a Hard Place: Politics, Midnight Regulations, and Mining, 55 ADMIN. L. REv. 551, 567-68 (2003) (describing how westerners have used the Senate to protect the mining industry against eastern interests). The regional nature of the conflict goes back to the 1866 federal law, with easterners seeking federal revenue and westerners seeking free access. See CARL J. MAYER \& GEORGE A. Rlley, Public Domain, PRIVATe Dominion 48-53 (1985) (recounting debate). As a regional, capital-intensive industry, mining has few employees to provide a basis for political support. Hardrock mining, which excludes coal mining and non-metal mining such as gravel and clay, hit peak employment in 1916, when 195,438 were directly employed-almost one-half of one percent of the labor force. More than four times more men were also employed in coal and nonmetal mining at that time. 1 Historical STATISTICS OF THE UNITED STATES: Colonial TIMES to 1970 , at 608 (1975). Today hardrock mining employs about 31,000 , or one-quarter of onethousandth of a percent of the labor force. DEPARTMENT OF LABOR, EMPLOYEES ON NONFARM PAYROLLS BY DETAILED INDUSTRY, at tbl. B-12, at $\mathrm{ftp} / / / \mathrm{ftp}$. bls.gov/pub/suppl/empsit.ceseeb12.txt (last visited July 10, 2004). The number of workers has little to do with market value of output, which was about $\$ 9$ billion in domestic metal production in 2001. NAT'L MINING ASsOCIATION, MINING IN THE UNITED STATES, http://www.nma.org/pdf/states_01/us2001.pdf (last visited July 10, 2004). 
Mining is thus an economically vulnerable activity ${ }^{52}$ that has little protection from political risks: It generates enormous wealth yet has significant capital at risk; it has only a regional political base; and the industry's workforce is relatively small, eliminating a potent source of political support. Secure property rights are thus critical to inducing investment in long-term mining operations. ${ }^{53}$

The second key characteristic of the industry is the high cost of locating new mineral resources. Locating new deposits is a lengthy and costly process, typically costing $\$ 150,000$ to $\$ 250,000$, with another $\$ 500,000$ to $\$ 1,000,000$ necessary to determine whether to proceed with the site. ${ }^{54}$ The result is that "mining has one of the lowest returns on investment of major industries. ${ }^{\text {"55 }}$ A successful mining operation requires large capital investment in extraction, significant intellectual capital (patents, trade secrets), and the ability to ride out fluctuations in commodity prices and currencies. Successful operators of enterprises are therefore likely to be companies with large amounts of capital at risk, increasing their vulnerability to expropriation.

To put these risk factors into perspective, imagine that receiving the right to develop minerals on any given block of land is akin to buying a lottery ticket; that is, the payoff is randomly awarded. ${ }^{56}$ The combination of the political risk and capital intensity mean that a mining lottery ticket holder must consider the payoff if she wins as requiring that the winnings be left in an unlocked room for ten years before she spends any of it, with the room's address and amount of money in the room published daily in the newspaper. Such a lottery ticket obviously would be worth substantially less

52 Note that we are not contending that mining does not generate significant revenue for mineral rights holders; it does-just as a winning lottery ticket generates significant revenue for its holder. But to generate those revenues, mining rights holders must first do two expensive things. First, they must spend a great deal of money locating the mineral resources because mining rights are not like lottery tickets in at least one critical respect: the payoff is not random but based on the mineral characteristics of the land. Investing in learning where to look therefore improves the chance of a winning "ticket." Second, rights holders must sink a large sum of money into the ground for a long time to get their reward. Both of these steps have costs: geologists must be hired and other opportunities to invest must be foregone, to list only two of the most obvious. Mineral rights development thus depends heavily on whether a mining law regime provides incentives to develop such knowledge and security for such investments.

53 See Henning Bohn \& Robert T. Deacon, Ownership Risk, Investment, and the Use of Natural Resources, 90 AM. ECON. REV. 526 (2000) (showing that insecure ownership has an adverse impact on mineral exploration and production); OTTO \& CORDES, supra note 48 , at 1-51 ("Security of tenure ... ranks as one of the most important pre-investment criteria mentioned by international mining companies.").

54 LACY, supra note 46 , at ch. 2, pt. A.7. These costs are caused by the rarity of viable deposits. See NAT'L RESEARCH COUNCIL, supra note 45 , at 23 ('Known ores constitute less than $0.01 \%$ of the metal content of the upper $1 \mathrm{~km}$ of continental crust."). As one example, consider that the number of mineral sites investigated in Canada to discover a single significant deposit was about 1,000 in 1969 and the odds have probably not improved. Id. at 24 .

55 NAT'L RESEARCH COUNCIL, supra note 45 , at 24.

56 Of course, the payoff is not randomly awarded in mining. We discuss the incentive issues that stem from the nonrandom nature in Part III.B, infra 
than one which provided the winner with a secure transfer of the winnings to a bank account.

The third key characteristic is that most of the unclaimed mineral reserves in the United States are located on federal land. ${ }^{57}$ This follows from mining's dependence on western locations. Since a large share of the land in these states is owned by the federal government, most undeveloped mineral resources are located on federal land. ${ }^{58}$ The predominant federal ownership of untapped (and unknown) mineral resources means there is a single dominant seller of unmined land suitable for mineral exploration: the federal government.

\section{B. The Structure of the Mining Law}

Although there is a well-developed body of law dealing with a number of details of the operation of the Mining Law, ${ }^{59}$ for our purposes the key features of the Mining Law are that issuance of the property rights under the law is not discretionary and that there is no significant transfer fee. ${ }^{60}$ There are many important criticisms of specific details of the Mining Law and the judicial and administrative interpretations of it. ${ }^{61}$ These are often mingled with attacks on the free access principle. We focus on the principle, not the doctrine, separating the critique of free access from the criticism of its specific and imperfect implementation in the Mining Law. ${ }^{62}$

Once a claimant has satisfied the objectively verifiable requirements of the law, the property rights must issue without a significant payment. These are crucial distinctions between the Mining Law and alternatives such as leasing systems or auctions, the main alternatives proposed by the Mining Law's critics. In leasing systems, the determination of whether to provide a lease is generally discretionary, ${ }^{63}$ and auction systems often require discretionary choices by government actors of the particular resources to auction and the structure of the auction. ${ }^{64}$ Both, of course, also require significant transfer fees. We next briefly examine how these features of the Mining Law combine in operation, describe the most important changes in

57 See supra note 50 and accompanying text.

58 The Bureau of Land Management and U.S. Forest Service manage $43 \%$ of Arizona land, $45 \%$ of California, $27 \%$ of Montana, $80 \%$ of Nevada, and $50 \%$ of Wyoming. NAT'L RESEARCH CoUnCL, supra note 49 , at 18.

59 GORDON \& VANDOREN, supra note 31 , at para. 8 ("From that simple regime numerous complications arise.").

60 These features are also the ones that draw the most attention from others. See LESHY, supra note 4, at 25 ("[W]hat preoccupies friend and foe alike is the idea of free, self-initiated access to the federal lands.").

61 See id. (giving a comprehensive critique of the Mining Law).

62 See GORDON \& VANDOREN, supra note 31, for a detailed critique of the Mining Law on market principles.

63 W. B. Prince, Mining Law in the United States, 7 MrN. REsourCES EngINEERING 393, 395 (1998).

64 See infra note 174 and accompanying text (noting claims of bias in coal auctions in the U.S. in the $1980 \mathrm{~s}$.) 
the Mining Law since its passage, and summarize the existing explanations for the perseverance of the Mining Law.

\section{Obtaining Property Rights}

To stake a claim under the Mining Law, one must select eligible federal land $^{65}$ and then locate a valuable mineral deposit. ${ }^{66}$ Once an individual has started exploration work on land covered by the Mining Law, she may locate a claim to an area she believes contains a valuable mineral covered by the Mining Law. Claimants now pay a $\$ 100$ annual fee to maintain their claims; ${ }^{67}$ before 1993 claimants were required to perform $\$ 100$ of annual development work. $^{68}$ In addition, Congress has recently required payment of a $\$ 25$ claim location fee for first-time locators. ${ }^{69}$ Claim holders may make multiple claims and need not ever produce minerals; ${ }^{70}$ no royalties or payments beyond the modest fees described above must be paid to the federal government if resources are located. ${ }^{71} \mathrm{By}$ diligently searching for a mineral and actually occupying the land, a claimant acquires rights against other potential claimants under the doctrine of pedis possessio. ${ }^{72}$ Claims at this stage may be challenged by other claimants if the claims are not developed, however. ${ }^{73}$

Claimants who have performed at least $\$ 500$ of development work and determined that their claims are of an economically viable mineral deposit may file a patent ${ }^{74}$ application to receive fee simple title to both mineral and surface rights or just the mineral rights at the claimant's option; since 1989 a $\$ 250$ fee per application, plus a separate $\$ 50$ per claim fee, is also required..$^{75}$ Once the patent application is granted, the applicant must pay $\$ 2.50$ per acre

65 Uram, supra note 38, at 191 ("A mining claim is located today in the same way as in 1872 , by physically outlining the boundaries of land to be explored and placing stakes in the ground at the corners of a claim and at the point of discovery.").

66 Id. ("If the claimant discovers a valuable mineral deposit on a properly located claim, the claim holder ... may apply for a patent and obtain ownership.").

6730 U.S.C. $\S 28 f(a)(2000)$.

68 Id. $\S 28$.

69 HUMPHRIES, supra note 25 , at 2.

70 See LESHY, supra note 4, at 355-56 (discussing the "chronic problem of abusing the Mining Law for nonmineral ends"). Requiring production was suggested during the debate over the 1872 law but the idea was dropped. MAYER \& RILEY, supra note 51, at 54 .

71 Uram, supra note 38 , at 191 ("The miner pays no royalty on production or rent to the United States, no matter how valuable the claim.").

721 AMERICAN LAW OF MINING 30-15 (Cheryl Outerbridge ed., 2d ed. 1998). The doctrine protects one who in good faith stakes a claim while diligently working toward discovery.

73 See LESHY, supra note 4, at 266-69 (describing pros and cons of patent for rights owner, including security against challenges).

74 "Patenting" under the Mining Law is something of a term of art, but is related to the intellectual property use of the term and has a similar meaning under the Mining Law. See Edmund W. Kitch, The Nature and Function of the Patent System, 20 J.L. \& ECON. 265, 271-75 (1977) (comparing the intellectual property patent system to the 19th century mineral claim system and prospecting laws relating to mining).

7530 U.S.C. $\S 29$ (2000); 43 C.F.R. $\$ \S 3862.1,3862.2$ (2003) (listing fees required). 
for placer claims ${ }^{76}$ and $\$ 5$ per acre for lode claims. ${ }^{77}$ Claims are limited to approximately 20 acres. $^{78}$ The most significant restriction that must be overcome to obtain a patent is the requirement of discovery of a valuable deposit $^{79}$ - ${ }^{4}$ the sine qua non of a valid mining claim. ${ }^{\text {"80 }}$

As the General Accounting Office noted, issuance of a patent means the claim has become private property, which "removes any opportunity the federal government has to collect revenues on the minerals extracted, because the government no longer has title to either the minerals or the land." ${ }^{81}$ Of course, the government may still tax the property in the same fashion it does all other property; income taxes on income collected from economic activity, property taxes, and so on are still available to the government.

The patent process is straightforward. A claimant first requests a mineral survey, which must be done by a surveyor approved by the Bureau of Land Management (BLM) ${ }^{82}$ The surveyor, who is technically working for the federal government and not for the applicant, ${ }^{83}$ submits the results to the BLM state office, with a copy for the applicant. The applicant must post a copy of the plat on the claim, together with a notice of intent to seek a patent, post a notice at the BLM state office, and publish a notice in a local newspaper for at least 60 days. $^{84}$ The applicant must also submit evidence of title, proof of citizenship, proof of the completion of $\$ 500$ of labor, the filing fee, and the purchase price. ${ }^{85}$ The federal government then verifies the discovery and issues title to both the surface and mineral estates. ${ }^{86}$ These

7630 U.S.C. $\S 37$ (2000); $\S 43$ C.F.R. 3863.1 (2003). Placer mining is that in which minerals "are extracted from stream or beach sediments by gravity separation using water." NAT'L RESEARCH COUNCIL, supra note 45, at 25.

7730 U.S.C. $\$ 37(2000)$. Lode claims are, roughly, those that cover the classic vein of a mineral in a defined body of rock. NAT'L RESEARCH COUNCIL, supra note 45, at 244.

78 Placer claims cannot be larger than 20 acres. 43 C.F.R. $\$ 3832.22$ (2003). Lode claims may be slightly larger. See id. (limiting lode claims to 1,500 x 600 feet). See also HUMPHRIES, supra note 25 , at 2 ("A placer claim is usuaily limited to 20 acres but a lode claim may be slightly greater than 20 acres.").

79 See 1990 Senate Hearings, supra note 4, at 30 (statement of Mr. Cy Jamison, Director, Bureau of Land Management) ("It is very difficult to meet the discovery requirement. We go out there and check. We make sure that you have met the discovery requirement of finding a valuable mineral."). We plan to address the shifting nature of the discovery rule in future work on the political economy of the evolution of the Mining Law and efforts to amend it. Here we note only that until the administration of Theodore Roosevelt the discovery requirement meant that "by and large any miner who was willing to risk his life and fortune in pursuit of minerals was welcome to it," limited only by the idea that it be a "prudent man" who was willing to take the risk. John C. Lacy, Historical Overview of the Mining Law: The Miners' Law Becomes Law, in THE Mining LaW of 1872: A LEgal and Historical ANAlysis 13, 43 (1989). Starting with Roosevelt, however, the Department of the Interior began a "new era of federal control" that led to a more stringent "marketability" test being imposed administratively. Id.

801 AMERICAN LAW OF MINING, supra note 72, at 30-15.

81 GENERAL ACCOUNTING OFFICE, supra note 25 , at 11.

8230 U.S.C. $\S 29$ (2000); 43 C.F.R. $\$ 3861.5-2(2000)$.

83 Waskey v. Hammer, 223 U.S. 85,92 (1912).

8443 C.F.R. \& 3862.4-1 (2000).

8530 U.S.C. \& $29(2000)$.

86 The process between application for a patent and issuance of a patent changed in the 
requirements simply ensure that any other potential claimant has notice that the land is about to be privatized, that there is indeed a valuable mineral resource present, and that the boundaries of the claimed area are settled in advance.

\section{The Evidence on the Giveaway Claim}

Those who discover mineral resources on federal land are entitled to receive title to the resources (and the surface estate if they so choose) for no more than a de minimus payment to the government. This is the feature that is regularly criticized by those opposed to the Mining Law ${ }^{87}$ and the one that seems the most counterintuitive: How can the government justify giving away valuable minerals?

One part of the answer is that procuring the property rights requires more than paying the small fee-the claimant must locate the mineral deposit, which as noted above is often a considerable expense. As a result, the property rights are not given away for nothing; they are awarded based on effort in locating the minerals. ${ }^{88}$ Of course, location expenses must be paid regardless of the system of allocating resources. It is transfer payments that are not necessary under the Mining Law (and some other allocation methods such as a lottery) but are under the most prominent proposed alternatives, auctions and leasing.

1990s. Prior to the Clinton Administration, a First Half Final Certificate (FHFC) was issued after the application. Patrick Garver \& Mark Squillace, Mining Law Reform-Administrative Style, in

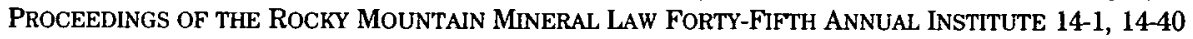
(1999). The issuance of the FHFC and payment of the purchase price were sufficient to vest the right to the patent. See Benson Mining \& Smelting Co. v. Alta Mining \& Smelting Co., 145 U.S. $428,431-32$ (1892) ("In other words, when the price is paid the right to a patent immediately arises."). Following this, a BLM mineral examiner would verify that there had been a discovery of valuable minerals. If the discovery was verified, the Secretary of the Interior would then issue a Second Half Mineral Entry Final Certificate (SHFC) and the patent. Garver \& Squillace, supra at 14-40. The Clinton Administration made changes to delay vesting by not accepting the purchase price as early in the process and moving to eliminate the FHFC, replacing it with a Mineral Entry Final Certificate. Garver \& Squillace, supra, at 14-41. Regardless of these complications, the basic principle has remained unchanged: Discovery and development, with no more than minimal payment to the federal government, can produce title to mineral resources and the surface estate.

87 See MAYER \& RILEY, supra note 51, at 79 ("The most persistent target of criticism has been the transfer of valuable minerals to private users with little or no return to the public.").

88 There is an important distinction between the costs of location, which are an investment in a claim, and the payment of a fee for ownership, which is a pure resource transfer. Expenditures on license fees are simply resource transfers from the license holder to the seller (in this case, the government). As these fees increase, the buyer of the license has fewer resources available to use to develop the license. Correctly balancing the objectives in an auction is a complex design problem. See Peter Cramton, Spectrum Auctions, in 1 HaNDBOoK of TElecommunications Economics 606 (Martin E. Cave et al. eds., 2002) (describing auction theory). Locating a resource produces something of value (knowledge of the location of the resource). Payment of a fee for title does not, since the payment is unrelated to the goods produced. 
A second part of the answer is that the giveaway charge is based on ex post information on land values, not on ex ante estimates. ${ }^{89} \mathrm{By}$ this reasoning, state governments "give away" too much when they "sell" multimillion dollar lottery jackpots to individuals in exchange for a single dollar used to purchase the winning ticket. ${ }^{90}$ Of course, the millions of losing tickets are not such a great investment. Similarly, while mining claims that prove profitable are a bargain, the many that do not are not. The problem is that it is difficult to predict in advance which claims will fall into each category, even if not quite as difficult as predicting the winning lottery number. ${ }^{91}$

We do have some evidence concerning the value people place on the rights they can claim under the Mining Law. The substitution of the fee for the annual work requirement brought about a substantial decline in the number of claims, reducing them from 1.2 million in FY1989 to less than 300,000 in FY1993, ${ }^{92}$ despite the fee's low level. The number of claims also fluctuates substantially with mineral prices. ${ }^{93}$ The reaction to the $\$ 100$ fee and the sensitivity of claims holders to mineral prices suggest that the value of holding a claim is relatively low. If an increase in costs of $\$ 100$ per year cut the number of claims by $75 \%$ in four years, ${ }^{94}$ the value of those claims dropped must have been less than the claim holders' anticipated expenditures to retain them.

Something besides the claim itself must be necessary to create value. As we suggested earlier, that something is an investment in knowledge about the value of mineral rights on the claim. A claimant must show actual physical disclosure of a valuable mineral resource deposit ${ }^{95}$ and "it must be shown that the mineral can be 'extracted, removed, and marketed at a profit'-the so-called 'marketability test." 96 Where that knowledge is missing, the claims have low value. In short, mineral rights on land about which there is not specific knowledge of mineral deposits (as is true of virtually all federal land) are essentially worthless. It is the specific knowledge about the prospects for minerals that is valuable, and the cost of acquiring that knowledge is not based on the cost of acquiring the legal rights to the minerals.

89 GORDON \& VANDOREN, supra note 31, at paras. 20-26.

90 See id. at para. 120 ("We would not claim that the winner of a lottery paid too little for the winnings because we recognize that most people who buy lottery tickets lose.").

91 The total value of the alleged "giveaway" is overstated as well by many critics. See id. at para. 38 (stating that "In principle, the true value of the 'giveaway' could be anywhere between zero and $\$ 231$ billion. The high figure is wildly implausible because mining has never been limited to claims so fabulously profitable that extraction costs are negligible. Zero, in fact, is a much more reasonable figure.").

92 HUMPHRIES, supra note 25 , at 3.

93 Id.

94 This overstates the increase in costs, of course. Before the $\$ 100$ fee requirement was imposed, claim holders had to perform $\$ 100$ of labor on their claim. HUMPHRIES, supra note 25 , at 2. For purposes of illustration we are assuming that the labor cost the claim holder nothing.

95 Lara v. Sec'y. of the Interior, 820 F.2d 1535, 1537 (9th Cir. 1987).

96 United States v. Coleman, 390 U.S. 599, 600 (1968) (quoting the Secretary of the Interior). 
The most surprising feature of the patent process is how little land has been privatized under it. Despite claims that it is a rampant giveaway, from 1867 to $2000^{97}$ only 3.3 million acres were patented under the 1872 Mining Law and its predecessors, approximately $1.5 \%$ of all federal lands patented under all laws. ${ }^{98}$ By comparison, more than 213 million acres were transferred to individuals under the homestead laws and more than 73 million acres were transferred to the states for support of education. ${ }^{99}$ Further, claimants are not in a hurry to convert their unpatented claims into fee title. Between 1880 and 1912 more than a thousand patents a year were issued; the number declined into the hundreds thereafter and to fewer than 200 per year after the mid-1930s. ${ }^{100}$ There is clearly no rush to privatize mineral lands.

\section{Narrowing the Scope}

Since 1872 Congress has gradually narrowed the scope of the Mining Law. The law originally applied to all minerals except coal. ${ }^{101}$ Over time various minerals have been withdrawn from the Mining Law. Oil, gas, oil shale, phosphates, and sodium were removed from the Mining Law by the Mineral Leasing Act of $1920,{ }^{102}$ and common variety minerals (e.g. stone, sand, gravel, cinders, and pumice) were removed by the Materials Act of $1947^{103}$ and its 1955 amendments. ${ }^{104}$ In addition to the withdrawal of minerals, Congress has reduced the scope of the Mining Law by withdrawal of some types and parcels of federal lands from its coverage. The 1872 law never applied to more than lands originally acquired by the federal government through treaty; it has always excluded lands acquired by the federal government through purchase, condemnation, or gift from a state or

97 Since 1994 there has been a congressionally imposed moratorium on the granting of new patents on claims filed after 1994. See, e.g, Department of the Interior and Related Agencies Appropriations Act, 1995, Pub. L. No. 103-332, § 112, 108 Stat. 2499, 2519 (1994); Department of the Interior and Related Agencies Appropriations Act, 1996, Pub. L. No. 104-134, $\S 322,110$ Stat. 1321-156, 1321-203; see also Randy Hubbard, The 1872 Mining Law: Past, Present and Future, 17 NAT. RESOURCES \& ENV'T 149, 150-52 (2003) (discussing moratoria); John D. Leshy, Mining Law Reform Redux, Once More, 42 NAT. RESOURCES J. 461, 465 (2002) (noting resumption of processing of pre-1994 patent claims).

98 Humphries, supra note 25 , at 3 . That relatively few acres have been claimed is rarely mentioned by critics of the Mining Law. The Environmental Working Group, for example, highlights that "an estimated 216 million acres of federal land are open for mining under the Mining Law of 1872, or about one out of every 11 acres of land in the entire U.S." ENVIRONMENTAL WORKING GROUP, supra note $30, \S 2$. What they do not mention, however, is that all those acres have been available for well over 100 years and have not yet been claimed.

99 Gary M. Anderson \& Dolores T. Martin, The Public Domain and Nineteenth Century Transfer Policy, 6 CATO J. 905, 908-09 (1987), available at http:/www.cato.org/pubs/journal/cj6n3/cj6n3-11.pdf.

100 LESHY, supra note 4 , at 266 .

101 HUMPHRIES, supra note 25 , at 1.

10230 U.S.C. $\S \S 181-193,195,201-209,211-214,223-229,241,251,261-263$ (2000).

10330 U.S.C. $\$ \S 601-604(2000)$

104 HUMPHRIES, supra note 25, at 3. 
private owner. ${ }^{105}$ Other federal lands have also been withdrawn over time, such as most national park land. ${ }^{106}$ As we will discuss below, we believe these withdrawals reflect responses to specific political pressures rather than concern over the appropriateness of privatizing mineral rights or the free access principle. ${ }^{107}$

\section{Explaining the Institution}

How can such a system be justified? Why should public resources be turned over to private interests without the public receiving something in exchange? The answer has historically been that the Mining Law was intended "to promote mineral exploration and development on federal lands in the western United States, offer an opportunity to obtain a clear title to mines already being worked, and help settle the West." 108

This part of the explanation is correct as far as it goes. It is certainly true that the Mining Law grew out of the experience of the nineteenth century mineral rushes, particularly the gold rushes that began with the California Gold Rush of 1848-49. ${ }^{109}$ Before that the federal government lacked a consistent approach to mineral deposits on federal land, following a variety of strategies depending on the location. ${ }^{110}$ The principle of preemptive rights can also clearly be traced back to miners' experience in the West, where practical issues made it impossible for any other system to be adopted. ${ }^{111}$ In California, for example, gold was discovered just as the region became American territory. At a time when there was no official civil authority in place, existing property records can be best described as chaotic, and law enforcement resources were nonexistent. ${ }^{112}$ Miners had no practical choice but to create their own institutions to regulate access to the commons-had they delayed, others would have taken the gold long before Congress had organized a territorial government. Thus although formally the mineral resources in the West belonged to the federal government, ${ }^{113}$ as a practical matter they were an unowned common pool resource much as ocean fish in unclaimed waters are today. ${ }^{114}$

105 Id. at 1.

106 See Sanjay Ranchod, Note, The Clinton Nat'l Monuments: Protecting Ecosystems with the Antiquities Act, 25 HARv. ENvTL. L. REv. 535, 546-49 (2001) (describing withdrawal history).

107 See infra Parts IV.B, IV.C.

108 HuMPHRIES, supra note 25, at 1.

109 See Morriss, supra note 2, at 620 (noting relationship between the Mining Law and California miners' institutions).

110 LESHY, supra note 4, at 9-11.

111 Davis, supra note 1, at 897-98 ("The gold seekers were before long so firmly established on the land that it would not have been practicable to evict them, had the government so desired.").

112 See id. at 897-98 (describing conditions in the gold fields); Morriss, supra note 2, at 59398 (same).

113 Davis, supra note 1, at 897 ("It cannot be questioned that the ownership of the gold was vested in the United States, nor that there were then no laws which permitted either the lands themselves or the minerals in them to be appropriated by private individuals.").

114 See Jonathan H. Adler, Legal Obstacles to Private Ordering in Marine Fisheries, 8 RoGER 
The history is not enough to explain the Mining Law's existence today, however. Miners developed the means to privatize the commons and the federal government later ratified their solution. ${ }^{115}$ Civil institutions eventually came to California, property records became orderly, and public law enforcement began. If the Mining Law merely reflected the historical accidents that led to its creation, why maintain an ad hoc arrangement designed to deal with conditions that no longer exist? Moreover, the historical origins do not explain another crucial aspect of the Mining Law's persistence. Federal land policy in the nineteenth century was primarily about disposal of the public domain (through land grants to railroads, states, and private individuals). The Mining Law was simply one of many means to allow access to and exploitation of certain assets on public lands. The only remaining question is why the Mining Law persists despite the demise of the other disposal statutes. ${ }^{116}$ Most of the Mining Law's critics conclude it must be because of the power and influence of the recipients of this great "giveaway."117

The historical explanation for the Mining Law summarized above is accurate as far as it goes. The Mining Law was part of larger set of land disposal statutes and it was intended to (and did in fact) encourage settlement and economic activity in the American West. That is not the entire story, however. Congress considered and rejected asserting federal ownership of the mineral resources in the new land. ${ }^{118}$ That rejection raises the possibility that Congress knew what it was doing when it gave away the

WILLAAMS U. L. REv. 9, 11-18 (2002) (describing common pool problems in fisheries).

115 R.S. Morrison \& EmILIO D. DeSoto, Mining Righ's in The Western States and TERRITORIEs 10 (10th ed. 1900) ("From the time ... of the discovery of gold in California, the government had tacitly recognized the occupation of its mining lands as such.").

116 See John D. Leshy, Reforming the Mining Law; Problems and Prospects, 9 PUB. LAND L. REv. 1, 3 (1988) (commenting that "it is astonishing that the Law has escaped fundamental change").

117 Id. at 3,17 (arguing that divisions among miners prevented change until recently and that an even distribution of power between the mining industry and environmental pressure groups blocks change today); see also HUMPHRIES, supra note 25, at 4 (noting that critics consider the Mining Law to be a "giveaway"); Robert L. Glicksman \& George Cameron Coggins, Hardrock Minerals, Energy Minerals, and Other Resources on the Public Lands: The Evolution of Federal Natural Resources Law, 33 TULSA L.J. 765, 777 (1998) (stating that "the most important of these giveaways took the form of the General Mining Law . . o of 1872"); Douglas A. Kysar, Law, Environment, and Vision, 97 Nw. U. L. REv. 675, 707 (2003) (terming the Mining Law a "giveaway"). Although we like a "special interest robs general public blind" story as much or more than most people, there are reasons to be suspicious of it in this context. For example, why are there still resources waiting to be grabbed? We discuss these issues below. For an extended treatment of the special interest story, see MAYER \& RILEY, supra note 51.

118 See, e.g., LESHY, supra note 4, at 14-16 (summarizing debate); Walter W. Bradley, Foreword to A.H. RicketTS, CAL. DEPT. OF NATURAL RES. BULL. No. 98, AMERICAN Mining LaW, at xix, xxvi-xxvii (1931) (recounting procedural history of debate); Colby, supra note 3, at 372 (noting that first draft of 1866 law included a royalty requirement that was dropped from the final version); John C. Lacy, The Historical Origins of the U.S. Mining Law's and Proposals for Change, 10 NAT. RESOURCES \& ENv'T 13, 17 (1995) (noting the 1866 mining law "was fully debated and was clearly the will of Congress."); $i d$. at 18 (summarizing influential report by Commissioner of Mineral Statistics arguing for free access). 
public claim to mineral rights. ${ }^{119}$ Rossiter Raymond, a mining engineer and Commissioner of Mineral Statistics in 1869, recommended to Congress a system that was "broad, simple, and, as far as possible, automatic."120 Moreover, history does not explain the Mining Law's continued existence. Its persistence may be an anomaly or the result of particular interest groups' successful lobbying campaigns. It may also be the result of the happy coincidence that the Mining Law's provisions unintentionally resulted in an institution that meets an important social need.

This latter possibility should not be dismissed out of hand. Unintended consequences of institutions are an important feature of the growth of western legal systems. Hernando de Soto has argued, for example, that property rights institutions have led to developed nations' prosperity in comparison to underdeveloped and former communist countries' poverty even as most westerners remain unaware of the reasons for their success. ${ }^{121}$ Nobel laureate Friedrich Hayek stressed the importance of unconscious evolutionary development of legal institutions in his economic analysis of law. ${ }^{122}$ While we must be wary of the danger of circular reasoning that lies in explaining all existing institutions as somehow evolved to provide efficiency and efficiency as the set of outcomes provided by existing institutions, we must also be wary of assuming that all legal institutions are merely what their creators intended them to be.

We thus have two competing explanations for the Mining Law's survival. In the dominant account, the Mining Law is the relic of a bygone era, persisting through a combination of inertia and special interest lobbying. In the second, the Mining Law is an institutional response to the incentive problems of public ownership of resources and an effective, evolved mechanism for solving the problem of determining how to use those resources. In the remainder of this Article, we make the case that the latter provides the better explanation of the important features of the Mining Law and accounts for its survival.

\section{SOLVING PROBLEMS}

Assuming that mining is an acceptable activity in at least some locations, a successful mining law regime must solve a number of interrelated incentive problems. The law must provide the following:

119 Of course, purposeful choice by politicians is not evidence of social utility.

120 Lacy, supra note 79, at 39 (quoting R.W. RAYMond, Mineral Resources of THE STATES AND TERRITORIES, H.R. EXEC. DOC. No. 40-54, at 216 (1969)).

121 HERNANDO DE SOTO, THE MYSTERY OF CAPITAL 105-151 (2000) (arguing that "The Missing Lessons of U.S. History" explain success of capitalism in the West and its failure in developing nations); see also Seth Norton, Population Growth, Economic Freedom, and the Rule of Law, in You Have to ADMit IT'S GetTing BetTer: From ECONOMic Prosperity to ENVIRONMENTAL QUALITY 143, 151-54 (Terry L. Anderson ed., 2004) (finding statistical link between respect for property rights and environmental quality).

1221 FRIEDRICH A. HAYEK, LAW, LEGISLATION, \& LIBERTY 85-88 (1973). 
1) sufficient incentives for individuals to locate mineral resources;

2) appropriate incentives for resource owners to develop their holdings; ${ }^{123}$

3) safeguards against corruption in allocation of resources from the public domain;

4) a framework for resolving conflicts over resource use between mineral resource development and other land uses and appropriate incentives for longterm management of the resources; and

5) methods to resolve environmental spillovers from mining sites that affect outsiders.

Because these problems differ from one another, the optimal solution for one is unlikely to also be optimal for another. Any particular mining law regime is thus unlikely to be the best with respect to all of these problems. The question will be what legal regime offers the best mix of solutions for the set of problems, not which offers the optimal solution to any single problem.

We argue that the Mining Law is an effective means of addressing the entire set of problems, not that it is more effective at solving every problem than every possible alternative. There are two implications of this argument. First, when the transition costs of change are considered, the alternatives to the Mining Law are not sufficiently more effective to provide the incentive for a change. This offers an alternative explanation of the persistence of the Mining Law in the United States to the standard special interest story. Second, nondiscretionary, low cost means of transferring hardrock mineral rights together with ownership of the surface estate from the public domain to private owners are better than the alternative of using the sale of those resources to generate income with respect to producing appropriate resource use decisions. We contend that the problems that the Mining Law solves particularly well are the more important ones, and so its effectiveness with respect to those problems makes it a preferred solution. We now turn to examining how the Mining Law addresses each of the incentive problems.

\section{A. Incentives to Locate}

Mineral resources are hard to find. Locating a claim and determining if it can be economically exploited usually requires significant investment, ${ }^{124}$ aside from occasional lucky breaks like the discovery of gold at Sutter's Mill in $1848 .{ }^{125}$ One obvious question about any set of mining laws is whether they reward the discoverer of mineral resources sufficiently to produce the effort needed to discover new deposits.

123 This includes providing secure title to the resources to allow sufficient investment to develop the economically viable resources located and providing incentives to consider the long term value of the resources in timing development. Secure property rights also appear to foster economic growth generally. See Martin Leschke, Constitutional Choice and Prosperity: A Factor Analysis, 11 CONST. POL. ECON. 265 (2000).

124 See supra note 54 and accompanying text.

125 See J.S. HOLLIDAY, THE WORLD RUSHED IN 33 (1981) (describing discovery of gold at Sutter's Mill). 
The rewards of locating minerals will obviously affect the amount of investment in exploration. If the locator of mineral resources receives all the rewards of her activity, she will invest more in locating minerals than if she must pay a tax or royalty on her outputs. One important determinant of a mineral law system's impact on investment is thus likely to be how much taxes, royalties, and other government-imposed regulatory costs (e.g. the cost of compliance with environmental protection regulations) reduce investors' returns. The debate over the Mining Law often features debates over the size of the incentive effect produced by the cost of securing title in the United States. ${ }^{126}$

There can be too much investment in discovery as well as too little. A slightly silly example ${ }^{127}$ can illustrate the point: if those who located minerals on public land received not only the mineral rights and the surface estate but also a bonus of $\$ 10,000$, there would likely be "too much" production. Outside of textbooks and classroom blackboards we think it unlikely that anyone could determine the exact optimal amount of a resource that should be produced, but some less nuanced judgments are possible. Taxing resource production will reduce the amount produced; taxing it at $90 \%$ marginal rates will dramatically reduce production, probably with the result that there will be "too little" by most social metrics. Subsidizing production and location will increase both activities; subsidizing them heavily will likely produce "too much."

Mining Law opponents recognize this and seek both to label the law as a subsidy ${ }^{128}$ and to substitute "moderate" royalty or lease payments. ${ }^{129}$ They argue that the public should get its "fair share" in exchange for allowing miners to dig up something the public owned. ${ }^{130}$ They contend that "giving away" title to these resources subsidizes miners just as surely as writing the miners a check would. Thus former Interior Secretary Bruce Babbitt staged a ceremony with an oversized "check" from the federal treasury to a mining patentee for $\$ 10$ billion when issuing the patent. ${ }^{131}$ We think this characterization is mistaken.

The Mining Law transfers title for a nominal fee but the title transfer is available only to those who have produced knowledge about the location of

126 See Bernard A. Gelb, Cong. Research Serv., Report No 94-540 E, Hardrock Mining, THE 1872 LAW, AND THE U.S. ECONOMY (1994) (summarizing debate over royalty rates), available at http://www.ncseonline.org/nle/crsreports/mining/mine-3.cfm.

127 This is only slightly silly because it bears an alarming resemblance to agricultural subsidy programs.

128 See supra notes 24-25 and accompanying text.

129 See LESHY, supra note 4, at 327-46 (advocating leasing system).

130 See James S. Rasband, The Rise of Urban Archipelagos in the American West: A New Preservation Policy?, 31 ENVTL. L. 1, 70 (2001) (noting that former Secretary of the Interior Bruce Babbitt's agenda included assuring "a fair return to the government for the minerals in the public lands by charging a royalty and other fees").

131 John H. Cushman, Jr., Forced, U.S. Sells Gold Land For Trifle, N.Y. Times, May 17, 1994, at A12. Babbitt's stunt has now entered the literature as proof of the giveaway. See ENVIRONMENTAL. WORKING GROUP, supra note $30, \S 2$ (noting the patentee received title to $\$ 10$ billion, "a return of one million dollars in gold for every one dollar paid to the federal government"). 
a valuable deposit. Indeed, the production of the knowledge about the deposit is what creates the value-there is no value without knowledge and, therefore, without investment in creating knowledge. The "subsidy" is payment for the production of knowledge, not a transfer payment unrelated to effort. Indeed, the incentive issues are similar to those involved with a different type of patent, the intellectual property kind. Many intellectual property (IP) patents result in little return to the inventor but a few do provide large returns. ${ }^{132}$ Because mineral patents are a reward for discovering knowledge, they are closer to IP patents than to a subsidy. The attractiveness of the Mining Law's approach is that what it subsidizes is the creation of tradable property rights in valuable assets rather than mineral production. The flexibility offered by the Mining Law to rights holders, allowing them to hold claims in various postures until they are ready to develop, also "provides much of the incentive for making the investment in the first instance." ${ }^{133}$ The fixed time period for most rights awarded under discretionary grant programs are more risky, thus reducing the investment. ${ }^{134}$

This is not the most important incentive effect of the Mining Law, however. Investors must consider not only the current royalty, tax, and other expense rates but also whether those rates are likely to change in the future. ${ }^{135}$ Although private landowners have a similar problem, government landowners cannot solve the problem in the same way private landowners do. Private landowners can negotiate binding contracts with mineral locators in advance of the mineral locators' investment to ensure that the discovery of mineral resources does not lead to a sudden change in price for

132 John R. Allison ET AL., VALUAbLe Patents 1 (George Mason Law \& Econ. Research Paper No. 03-31, UC Berkeley Pub. Law Research Paper No. 133, 2003) (exploring what makes patents valuable; noting relatively few patents are valuable and $99 \%$ of patents are not enforced); Mark Lemley, Rational Ignorance at the Patent Office, 95 Nw. U. L. REv. 1495, 1507 (2001) (same; also noting that $3.5 \%$ of patents are licensed for revenue).

133 Clayton J. Parr, Self-Initiation Under the Federal Mining Law, in THE Mining Law of 1872: A LEGAL AND HISTORICAL ANALYSIS 49, 65 (1989).

134 Id.

Exploration expenditures are much more risky [under discretionary grants of time limited rights], and therefore less likely to be made, because of a time limit that will not permit a deliberate program of investigation and data evaluation and because of the frightening uncertainty of being able to meet the regulatory test for discovery of a commercial deposit of minerals even if encouraging results are obtained.

Id.

135 See Linda A. Schwartzstein, Smoke and Mirrors: Tax Legislation, Uncertainty and Entrepreneurship, 6 CORNELL J.L. \& PUB. POL'Y 61, 77 (1996). Professor Schwartzstein writes:

To the extent the tax law is stable and certain, entrepreneurs can make useful predictions concerning the impact of taxation on their production plans. When tax law is changed frequently, however, the result is to add significant uncertainty to the planning process and to cause unexpected gains or losses simply due to changes in the incidence of taxation. Frequent change in tax legislation increases entrepreneurial uncertainty and, as a result, makes it more difficult for entrepreneurs to formulate plans and develop strategies. 
the resources found. Governments have a problem making credible commitments for the future through contracts, however. ${ }^{136}$

If a landowner contracted with a mining company to survey her property for gold, the landowner and the mining company could agree before the survey on the terms under which the mining company could mine the gold if it was found. A landowner who attempted to demand additional compensation after the discovery could be sued for breach of contract. ${ }^{137} \mathrm{~A}$ landowner who demanded a high price for the right to search ex ante would suffer in the competition with other landowners to attract mining interests. Market pressures would thus limit the landowners' ability to extract all the gains from discovery and legal institutions would prevent ex post changes in the original contract aimed at opportunistically expropriating value from the mining companies. ${ }^{138}$

Like private landowners, governments must make a credible commitment to the mining company not to expropriate all the gains from the discovery. Unlike private landowners, however, governments' large landholdings mean they face much less competition in the sale of mineral rights and so are less subject to market discipline. ${ }^{139}$ Even more important,

136 See Glenn Blackmon \& Richard Zeckhauser, Fragile Commitments and the Regulatory Process, 9 YALE J. ON REG. 73, 76-78 (1992) (discussing problem in context of utility regulation); Robert K. Fleck, When Should Market-Supporting Institutions Be Established? 16 J.L. ECON. \& ORG. 129, 133-37 (2000) (presenting a formal analysis of when commitment problems arise); Keith M. Hylton, Economic Rents and Essential Facilities, 1991 BYU L. REv. 1243, 1268-70 (1991) (discussing problem in context of energy facilities); Michael Kremer, Patent Buyouts: $A$ Mechanism for Encouraging Innovation, 113 Q.J. ECON. 1137, 1137-38 (1998) (discussing issue in context of patent law institutions and concluding that "[a]llowing government officials wide discretion to set payments to inventors ex post may lead to rent-seeking and to expropriation of investors after their research costs are sunk"); Klaus M. Schmidt, The Costs and Benefits of Privatization: An Incomplete Contracts Approach, 12 J.L. ECON. \& ORG. 1, 2-3 (1996) (discussing problem of commitment by governments in privatizations); see also Vicki Been \& Joel C. Beauvais, The Global Fifth Amendment? NAFTA's Investment Protections and the Misguided Quest for an International "Regulatory Takings" Doctrine, 78 N.Y.U. L. REv. 30, 119-20 (2003) (describing "signaling" theory of commitment to dispute resolution procedures by governments to prove to foreign investors that the government is trustworthy).

137 Despite some diligent effort, we were unable to locate a reported case in which a private landowner attempted to increase the price for the minerals after a lease was signed. In a sense, the absence of such a case is a better proof of how private contracting solves the problem than the existence of an example case would be. It is apparently so obvious that the lessee would prevail that landowners do not even attempt to squeeze the lessees.

138 Private firms can solve commitment problems by vertical integration, for example, which governments cannot. See Benjamin Klein et al., Vertical Integration, Appropriable Rents and the Competitive Contracting Process, 21 J.L. \& EcoN. 297, 298-302 (1978) (describing holdup problem and how integration can solve it); see also Paul L. Joskow, Asset Specificity and the Structure of Vertical Relationships: Empirical Evidence, 4 J.L. ECON. \& ORG. 95, 103-11 (1988) (describing theory, providing empirical evidence); Howard A. Shelanski \& Peter G. Klein, Empirical Research in Transaction Cost Economics: A Review and Assessment, 11 J.L. EcoN. \& ORG. 335 (1995) (describing evidence to support theory).

139 In the United States this is due to the predominance of federal land ownership in the West. Elsewhere it comes from governments' assertion of ownership of the mineral estate regardless of who owns the surface estate. 
governments have difficulty making credible long-term commitments. Certainly the government can sign a contract, and both reputational effects ${ }^{140}$ and constitutional guarantees can safeguard the language of the contract from forced changes. ${ }^{141}$ Governments cannot commit, however, not to use other margins to expropriate. ${ }^{142}$ For example, the government cannot commit that it will not change environmental regulations in such a way as to reduce the mining company's ability to operate under the terms of its lease. ${ }^{143}$ Moreover, as noted earlier, mining interests are particularly attractive targets for resource extraction by governments. ${ }^{144}$ Reducing the threat of expropriation is thus an important element in creating an incentive for mining operations to locate because their operations, which are generally not mobile in the short run and require large capital investments, make them vulnerable.

The Mining Law offers a means for the government to credibly reduce the possibility of later expropriation. By vesting the resource locator with full title to the minerals and, at the resource holders' option, with fee simple title to the surface estate as well, the government increases the value of the reputational constraint on its activities. ${ }^{145}$ If the government expropriates a

140 Louis Kaplow, Transitional Policy: A Conceptual Framework, 13 J. CoNTEMP. LEGAL IsSUES 161, 197 (2003) ("Successful governments need to find ways-whether through constitutional constraints or established norms - of committing themselves not to engage in [expropriation]."); Michael J. Klarman, How Great Were the "Great" Marshall Court Decisions?, 87 VA. L. REv. 1111, 1147 (2001) ("Even without a Contract Clause, or any judicially-reviewable constitution at all, governments have strong reputational incentives to comply with their own agreements and to refrain from interfering with those negotiated by private parties.").

141 See Douglas W. Kmiec \& John O. McGinnis, The Contract Clause: A Return to the Original Understanding, 14 HASTINGS CoNST. L.Q. 525 (1987) (discussing role of contract clause in protecting contractual bargains and historical background); Kyle D. Logue, Tax Transitions, Opportunistic Retroactivity, and the Benefits of Government Precommitment, $94 \mathrm{MrCH}$. L. REv. $1129,1146-47$ (1996) (discussing rationale for constitutional provisions committing government to keep contractual promises).

142 See Dao Lee Bernardi-Boyle, State Corporations for Indian Reservations, 26 AM. INDIAN L. REV. 41, 43-44 (2001) (discussing how inability to commit prevents outsiders from investing in tribal corporations).

143 An excellent discussion of commitment problems is given in Richard A. Epstein, Wilder v. Bernstein: Squeeze Play By Consent Decree, 1987 U. CHI. LEGAL F. 209, 222-23 (1987).

144 Mining capital is mobile in the long run, however; investment will flow away from insecure areas toward secure ones. See supra note 48 and accompanying text. On the impact of capital mobility in the long run, one commentator has stated,

The extent of exploration and exploitation of natural resources depends in part on the price, net of all taxes, at which economic agents expect that resources can be sold. That is, in the long run these activities have some price elasticity. There is a substantial element of economic rent in the return to many deposits of natural resources, nonetheless, especially once the resources have been discovered and exploitation has begun. Hence, in the short run the owners, rather than consumers, would bear much of any taxes on such resources.

Charles E. McLure, Jr., 1 SuPREME CT. ECON. REv. 69, 74 (1982).

145 As Professor Paul Joskow noted in the context of antitrust law, "[r]ecognizing the potential for opportunistic behavior ex ante, the transacting parties have an incentive to choose a governance arrangement (mutual hostages, written contracts, reputational capital, etc.) that mitigates the ex post holdup potential. ${ }^{n}$ Paul L. Joskow, Transaction Cost Economics, Antitrust 
vested property right, it must either pay under a takings claim or destroy value in all vested property rights under its jurisdiction by reducing the general level of security in property rights. The high costs of such an action would provide mining interests with important allies among property owners generally to resist such an action and would significantly reduce the gains from expropriation for the government.

Of course, the government still has margins under which it can harm the mining interest. Special environmental restrictions on mining activity may be imposed on private landowners as well as on lessees or contractors. While the regulatory takings doctrine provides some additional check on such forms of expropriation, that doctrine would be harder to apply in the absence of a clearly defined property interest. Creating a general property interest in land with mineral resources thus is a means for governments to increase the cost to their reputations of reneging on a commitment not to expropriate both directly and indirectly. This commitment in turn increases the value of the incentive to locate, leading to the discovery of more mineral wealth.

The specific implementation of the free access principle in the Mining Law does raise some issues. Because the Mining Law requires discovery to precede location, critics have argued that "Congress obviously thought that the mineral exploration it was authorizing . . . would continue to be a treasure hunt, confined to strata at or near the surface of the lands, where discoveries of valuable mineral deposits would be swift and certain, immediate and obvious." ${ }^{146} \mathrm{By}$ not recognizing modern exploration techniques and by protecting claims while exploration is occurring but before discovery, the Mining Law does fail to provide ideal incentives for discovery. ${ }^{147}$ The problem, however, is that the Mining Law incompletely implements self-initiated free access, not that it provides too much such access. Solving such problems requires only the addition of a straightforward relation-back rule to the existing structure and vigorous pruning of administrative and judicial accretions on the principle.

\section{B. Incentives to Develop}

Once located, miners must invest capital and other resources to convert the minerals in the ground into economically useful commodities. Depending on the resource, the location, and the purity of the deposit, the investment may be relatively small (e.g., simply picking up a gold nugget as occurred at Sutter's Mill in 1848) (148 $^{14}$ or quite high (e.g., constructing a processing facility, extracting low grade ore, disposing of waste from processing). ${ }^{149}$ Mineral rights owners' incentives to invest capital, as well as

Rules, and Remedies, 18 J.L. ECON. \& ORG. 95, 102 (2002).

146 LESHY, supra note 4, at 96.

147 The possible explanations for the imperfections in the law range from catering to special interests to simply bad drafting.

148 See supra note 125 and accompanying text.

149 See supra notes 54-55 and accompanying text. 
the incentives of others to provide capital for the rights owners to invest, depend on the ownership structure of the mineral rights. As noted in the previous section, increasing the value of the guarantee against expropriation increases the incentive to invest. That analysis applies with equal force to development, as does our caveat about the actual implementation of the free access principle.

A second issue exists as well. Mineral rights owners' incentives to maximize the total value of property, including surface rights, also depend on the structure of ownership. To see this, imagine that there are only two means of extracting a mineral resource. The first, "blast and scrape," is quick but environmentally destructive. The second, "long term management," involves additional investment to protect the environment and takes longer. The question for the landowner with secure property rights to both the surface and mineral estates will be which strategy maximizes her net return from the land. If there are valued uses of the surface estate, their value may induce her to select "long term management" over "blast and scrape." If, however, her property rights are not secure or she does not hold surface estate rights, then she cannot benefit from those uses and there will be no incentive to choose long term management. ${ }^{150}$ Note that we do not suggest that a landowner holding secure rights to both the surface and mineral estate will always choose "long term management" over "blast and scrape," merely that sometimes an owner with secure property rights will do so where an owner without such rights will rarely, if ever, prefer the environmentally-desirable method.

Of course, in the real world the choice is not binary but a continuum of management choices. Faced with such a continuum, residual claimant status can be a powerful incentive for environmentally sound land management practices on the margin. For example, a landowner who engages in conservation practices that increase wildlife habitat, and so enhance recreational values, may be rewarded by the marketplace for increasing the value of the land. ${ }^{151}$

For a resource owner with full title to the resources, the choice of development strategy will depend on the technology available, the resource price, and a host of other factors. ${ }^{152}$ For the resource owner with a title of

150 Some environmental critics seem to acknowledge this implicitly by criticizing instances in which the federal government has separated the surface and mineral estates, allowing the surface estate to be privatized and then selling the mineral estate. See ENVIRONMENTAL WORKING GrouP, supra note $30, \S 8$ ( "Mining patents give rise to dual land ownership and messy legal disputes.").

151 See Holly Lippke Fretwell \& Michael J. Podolsky, A Strategy for Restoring America's National Parks, 13 DuKE ENVTL. L. \& POL'Y F. 143, 155-56 (2003) (describing how International Paper increased profits by managing land for wildlife and recreational use in addition to timber production).

152 See Yoram Barzel, Economic ANALYSIS of PROPERTY RIGHTS 53 (2d ed. 1997) ("Together owners of labor and owners of land (bolstered by competition from other owners) will adopt the contract form that generates the largest net output value where maximization is subject to conventional productions costs as well as to the costs associated with the capture of wealth."); Cees Withagen, Optimal Extraction of Non-Renewable Resources, in HaNDBOoK of ENVIRONMENTAL AND NATURAL RESOURCE ECONOMICS 49, 51-56 (Jeroen C.J.M. van den Bergh ed., 
limited duration, the artificially shortened time horizon creates an incentive for overly rapid exploitation since resources left at the end of the period of ownership will be lost. ${ }^{153}$ As the time horizon shortens, the resource extraction problem in which a resource is owned only when removed from the land becomes similar to a commons exploitation, problem and a tragedy of the commons is more likely to result. ${ }^{154}$ Lengthening the time horizon of mineral rights owners is therefore critical to creating incentives to choose long term management over environmentally destructive strategies. ${ }^{155}$ Mineral law regimes that do not provide outright title produce duration related problems, as the end period will involve attempts by the outgoing resource owner to maximize its wealth at the expense of the residual claimant. ${ }^{156}$

1999) (surveying factors that determine optimal extraction).

153 This is true for physical resources as well as human labor. Owners of captive labor overexploit the captives:

Since the employer [of convict labor] gets no benefit from a leisurely work pace or pleasant working conditions, he will only allow maintenance consumption, that is consumption such as food, rest, and cleanliness required to maintain the convicts' work efforts.... Since the value of the convict depreciates to zero at the end of his term, the employer will let him depreciate physically, too.

Charles C. Cox \& Roger E. Meiners, Private Employment of Prison Labor, 17 J. PRIvate ENTERPRISE 18, 40-41 (2002). This argument was also made in favor of creating national oil companies generally. Paul Stevens, Nat'l Oil Companies: Good or Bad? A Literature Survey 9 (May 27, 2003) (unpublished draft, permission to cite on file with authors and Environmental Law), available at http://www.worldbank.org/wbi/B-SPAN/national_oil_companies/ national_oil_stevens_doc.pdf.

154 David Schmidtz, The Institution of Property, Soc. PHIL. \& POL'Y, Summer 1994, at 42, 4450 (1994), reprinted in ENVRONMENTAL ETHCS 361, 363-64 (David Schmidtz \& Elizabeth Willott eds., 2002) (explaining problems that arise when a resource can only be owned by removing it from nature).

155 See Richard A. EPSTEIN, Simple Rules for a Complex World 63 (1995) ("A rule that allows the first possessor ownership of the soil is not likely to lead to a premature exhaustion of the fields. The owner who stakes out a bit of land can then decide how and when to cultivate it and when to let it lie fallow. Indeed, the long-term time horizons give the right incentives against overuse."); Bruce Yandle \& Andrew P. Morriss, The Technologies of Property Rights: Choice Among Alternative Solutions to Tragedies of the Commons, 28 ECOLOGY L.Q. 123 (2001) (describing role of residual claimants in solving commons issues).

156 One theorist has described the problem as follows:

If the parties know in advance the termination point of their relationship, they confront a well-known "end-game" problem that threatens cooperation in the iterated prisoner's dilemma. Because cooperation will no longer be beneficial at the last adjustment opportunity, a party will be motivated to evade and capture its largest payoff. Anticipating that response, the other party has a similar incentive to evade at the next to the last opportunity (its own last opportunity for choice). Anticipating this, the other party evades at his previous opportunity and so on. Following this logic, the cooperative solution to the entire sequence unravels.

Robert E. Scott, Conflict and Cooperation in Long-Term Contracts, 75 CAL. L. REv. 2005, 2033 (1987). See also Robert E. Scott, A Theory of Self-Enforcing Indefinite Agreements, 103 Colum. L. REv. 1641, 1646 (2003) ("Ongoing relationships inevitably come to an end and thus all repeated interactions are subject to a familiar end-game problem. Indeed, in the limiting case, the anticipation of the last transaction may cause the entire cooperative pattern to unravel."); 
This problem is a general one in property law, applying between holders of present possessory interests in land (e.g., life estates, where the current possessor of the land's interest will terminate with her life) and future interests (e.g., vested remainders, where the rights holder will not gain possession until the expiration of a prior possessory interest). ${ }^{157} \mathrm{By}$ creating a single bundle of rights uniting the surface and mineral estates, the Mining Law avoids these temporal division problems.

Clear, easy to prove titles are crucial to ensuring appropriate decision making that takes a long run view of maximizing the asset's value. ${ }^{158}$ The Mining Law provides clear and unambiguous title to mineral resources, resolving both of these problems. It is not the only means of doing so, of course, as both an auction or lottery system of fee simple titles to mineral deposits with or without surface estates would accomplish the same thing. The Mining Law is clearly superior, however, to the alternatives of leasing or contract exploitation since neither would make the mining company the residual claimant on the resource absent extraordinary contractual provisions designed to mimic ownership.

Advocates of state ownership of mineral resources (and leasing has a state ownership component since the reversion remains in state hands) must confront a critical problem with such schemes: Government land management agencies (such as BLM) are not residual claimants. Public agencies do not reap direct benefits of increasing land value and do not bear the direct costs of reduced land value. ${ }^{159}$ Moreover, agencies' missions are often incompatible with environmental values. ${ }^{160}$ Government ownership

DONAID R. LEAL, PRoperty AND ENVRONMENT RESEARCH CENTER, POLICY SERIES PS-4, TURNING A PROFIT ON PUBLIC FORESTS, at para. 62 (1995) (noting that one reason for superiority of state management of public lands to federal management is that "the state and county have an overriding requirement to generate income from timber and other goods and services marketed from their forest lands"), available at http://www.perc.org/publications/policyseries/ turning_full.php? $\mathrm{s}=2$.

157 See Michael A. Heller, The Boundaries of Private Property, 108 YALE L.J. 1163, 1176-82 (1999) (discussing incentive problems in estates in land and future interests and means of overcoming them).

158 See Louis De Alessi, Private Property Rights as the Basis for Free Market Environmentalism, in Who OWNS THE ENvIRONMENT? 1, 29 (Peter J. Hill \& Roger E. Meiners eds., 1998) ("Environmental problems typically arise when property rights are not fully private and/or transaction costs are substantial. Under these conditions, individuals do not bear the full economic consequences of their decisions and thus lack the incentive to take them fully into account.").

159 GARY D. LIEBCAP, LOCKING UP THE RANGE 66 (1981).

160 The problems of public ownership can be seen in the environmentally destructive behavior of public agencies whose mission dominates their approach to the resources they control. The Bureau of Reclamation and Army Corps of Engineers are widely criticized for their fixations on building dams and flood control projects even where those projects are environmentally damaging and do not generate net benefits. Christine A. Klein, On Dams and Democracy, 78 OR. L. REv. 641, 667 (1999) (noting that "[b]etween 1930 and 1970, federal agencies joined in a forty year dam-building binge" and that "[d]am building, not public service, became the agencies' raison d'être, regardless of the relative costs or benefits of any particular project"). These agencies have missions and do not receive rewards for deviating from their missions, even when such deviations produce net benefits greater than accomplishing the mission. Id. at 669 ("The Bureau was seeking to protect its own interests by forging a mutually 
raises important conflict of interest problems as well. Professors James Otto and John Cordes concluded their 2002 review of international mining practices and public ownership of resources by noting, "The desire to assert control through ownership or equity participation places the government in the position of being both regulator and partner."161 Indeed, the result of this experience was a fundamental shift in the 1990s toward privatizing state mineral resources. ${ }^{162}$

American mining law differs significantly from mining laws elsewhere. In many countries, mineral resources are owned by the government, with limited private sector participation through joint development. ${ }^{163}$ The experience of those countries illustrates some of the incentive problems created by public ownership. Professors Otto and Cordes concluded that state enterprises in the mineral sector "were seldom able to achieve the decisional independence or abilities necessary to mirror private sector performance standards-they were unable to recreate the social insulation from governments and local demands historically provided by foreign investors." 164 By privatizing mineral resources, the Mining Law puts them into the hands of residual claimants. Doing so solves important incentive problems.

\section{Corruption}

Claims to mineral resources must be allocated among competing potential owners under any system. Where the allocation system includes significant discretion with respect to valuable resource claims ${ }^{165}$ and the overall legal system tolerates or encourages corruption, claims may be allocated according to criteria other than valuation. For example, a corrupt government may insist that shares in a project be allocated to government officials or their family members as a condition of approval of necessary permits. ${ }^{166}$ Corruption has been widespread in countries that have pursued

beneficial alliance with the corporate agricultural industry. That alliance enhanced the Bureau's power, as it joined agribusiness in lobbying for dam appropriations from Congress."); see generally William A. Niskanen, Bureaucrats and Politicians, 18 J.L. \& ECoN. 617, 618 (1975) (noting that bureaucracies have a strong incentive to support expansion of their budgets and staff).

161 OTTO \& CORDES, supra note 48 , at $1-43$.

162 Id. at $1-49$.

163 See Robin G. Adams, Dominant Strategic Themes of the Natural Resource Industry, 21 FORDHAM INT'L L.J. 492, 492-93 (1997) (describing nationalizations in 1960s and 1970s).

164 OTTO \& CORDES, supra note 48 , at 1-49.

165 Professor Toke Aidt lists the existence of discretion and economic rents as two of the three necessary conditions for corruption. The third is weak institutions that create an incentive for officials to exploit their discretion to rent-seek. Toke S. Aidt, Economic Analysis of Corruption: A Survey, 113 EcoN. J. F632, F633 (2003).

166 See Jennifer Wells, Fever: THE Dark MYSTERy of THE BRE-X GOLD RUSH 221-23 (1998) (describing how corruption in Indonesia was built around the ruler's family); Michael Peel, $A$ Push for Transparency on Oil Revenues, Fin. Times, Apr. 10, 2003, at 13 ("There are huge revenues being paid to these governments and, because there is no transparency, they are being stolen and misappropriated,' says Gavin Hayman, a campaigner for Global Witness, the Britishbased non-governmental organi[z]ation. 'Transparency is the start of a democratic debate about 
state involvement in mineral resource development. ${ }^{167}$ Because of their long time horizons and capital intensity, mining operations are particularly vulnerable to corruption problems. ${ }^{168}$

The result of corruption is to change competition for resources from one based on the ability to exploit the resource to one based on the ability to secure favors from corrupt officials. ${ }^{169}$ This has several pernicious effects:

- The need to share the rewards of developing mineral resources with corrupt officials reduces the expected value of deposits, making them less economically viable at any given price of the output;

- Rewarding the ability to bribe rather than the ability to produce means that less efficient producers will be relatively better off under a corrupt regime than under an honest regime; and

- The allocation of valuable rights through discretionary means can create corruption where it did not exist before. ${ }^{170}$

There is some evidence that Congress knew it would avoid corruption problems by giving away mineral resources. Prior land privatization programs that included discretionary awards of resources had experienced

the use of natural resources. "), available at $2003 \mathrm{WL} 15524478$.

167 See OTTO \& CORDES, supra note 48, at 1-48 ("The architects of development had overestimated the skills and integrity of national governments and state-owned companies. The intended meritocracy had not emerged. Rather it had evolved into a bloated system of inefficiency and pervasive corruption. The problem was endemic throughout the developing world."). There is an extensive literature on the link between corruption and mineral wealth in developing countries. See, e.g., XAVIER Sala-I-MarTin \& ARVIND SumRamanian, AdDressing THE NATURAL RESOURCE CuRSE: AN IluUSTRATION FROM Nigeria 5 (Nat'l Bureau of Econ. Research, Working Paper No. 9804, 2003) (finding that "stunted institutional development-a catch-all for a range of related pathologies, including corruption, weak governance, rent-seeking, plunder, etc.-is a problem intrinsic to countries that own natural resources such as oil and minerals"); Peel, supra note 166 (quoting nongovernmental organization spokesman as stating that "[t]here are huge revenues being paid to [developing countries'] governments [for oil] and, because there is no transparency, they are being stolen and misappropriated.").

168 See IAN E. MaRSHall, A SuRvey OF CORRUPTION ISSUES IN THE Mining \& Mineral SECTOR 37 (International Institute for Environment and Development, Report No. 15, 2001) ("The Mining sector has certain characteristics that make it especially vulnerable to corruption, including: the requirement for large initial capital expenditures; [and] lack of choice in location."), available at http://www.transparency.org/working_papers/mining_mineral/survey_of_corruption_marshall. pdf

169 See WORLD BANK, ANTICORRUPTION, at http://wwwl.worldbank.org/publicsector/anticorrupt/index.cfm (last visited July 10, 2004) (identifying "corruption as the single greatest obstacle to economic and social development."). The United Nations estimates that corruption costs $\$ 1.5$ trillion per year, or more than $5 \%$ of the world's economy. Corruption Costs $\$ 1.5$ Trillion A Year, U.N. Says, UN WIRE, Dec. 12, 2003, http://www.unwire.org/UNWire/20031212/449_11262.asp. Corruption can reduce gross domestic product by 0.5 to 1.0 percentage points. COMMISSION ON THE PRIVATE SECTOR AND DEVELOPMENT, UNITED Nations, UNLEASHING ENTREPRENEURSHIP: MAKING BUSINESS WORK FOR THE POOR 16 (2004), available at http://www.undp.org/cpsd/.

170 See, e.g., Jonathan Power, Nigeria Struggles Against the Curse of Oil, INT'L HERALD TRIB. Jan. 7, 2004, at 6 ("Oil and gas have blinded us... O Oil and gas have taken us away from the values that we used to know. Oil and gas have brutalized us." (quoting Nigerian President Olusegun Obasanjo)), available at http://www.iht.com/search/ihtsearch.php?Id=124036. 
serious corruption problems. ${ }^{171}$ Even where the programs involved transfers to states rather than private individuals, discretion produced problems. ${ }^{172}$ From the perspective of today's relatively low levels of corruption in the United States, it is easy to forget the high levels of government corruption that plagued the U.S. in earlier times.

Later experiences confirmed that theory: The 'Teapot Dome' scandal of the 1920 s involved federal reserved petroleum lands, ${ }^{173}$ and coal leasing in the 1980 s foundered on allegations that auctions were tainted by leaked information. ${ }^{174}$ Mining rights distributions in Canada in the Canadian Gold Rush produced numerous examples of corruption in allocating rights. ${ }^{175}$ More recently, the Army Corps of Engineers gave a 50-year, rent-free lease of lakefront property in Oklahoma to a developer who was coincidentally the finance chair for Senator James Inhofe, the chair of the Senate Committee on Environment and Public Works, which oversees the Corps. ${ }^{176}$ These examples are illustrative of the problem: where there is discretion there is potential for corruption and the appearance of corruption; where there are valuable resources to be allocated through discretion, rent-seeking behavior is likely to lead to corruption.

The Mining Law solves the corruption problem in a straightforward way. By minimizing government officials' discretion in allocating the rights, it also minimizes the opportunities for the officials to demand bribes as a condition of acting. ${ }^{177}$ Since no significant payment is required (other than

171 The lead land leasing program that pre-dated the California gold nush "was plagued with fraud by private citizens and General Land Office employees as well as with continual evasion of the terms of the leases, especially payment of rentals and royalties. In the end the government had to give up the scheme as unworkable." MARION CLAWSON, THE BUREAU OF LAND MANAGEMENT 126-27 (1971).

172 Bad behavior short of outright corruption has played a similar role in allocation of public lands. For example, Congress created a program to transfer "swamp" lands to states, under which over 60 million acres of federal land became state land. Anderson \& Martin, supra note 99 , at 909 . The theory behind the program was to encourage the states to undertake improvements in the land (e.g., draining the swamps), creating useful land that could be sold. Id. The states were permitted to select the surveyors who would determine which land was a "swamp" and so would become state property. Predictably they selected quite a bit of land that was not even damp. Anderson \& Martin, supra note 99, at 909 (noting that "most of this land granted was potentially valuable property, a result of the land selection system, which was carried out by agents appointed by the states themselves" and citing estimates that up to $75 \%$ of the land selected was "not swampy or even subject to serious flooding").

173 Clawson, supra note 171, at 128; see generally BURL NoGGLE, TEAPOT DoME: OIL AND POLITICS IN THE 1920S (1962) (describing the history of the scandal).

174 GORDON \& VANDOREN, supra note 31, at para. 82.

175 See Wiluam S. GReever, The Bonanza West: The Story of the WeStern Mining RUSHes, 1848-1990, at 364-67 (1963) (describing corruption problems in Canadian mineral rushes).

176 Douglas Jehl, How to Lease Federal Land From the Army Corps of Engineers and Avoid Rent, N.Y. Times, Mar. 13, 2003, at A20.

177 See Aidt, supra note 165, at F633 (noting that for corruption to exist, "the relevant public official must possess the authority to design or administer regulations and policies in a discretionary manner"). While there are many disputes under the Mining Law over boundaries and similar issues, these are largely disputes among claimants which do not involve governments as a party and are tried in state courts. Parr, supra note 133 , at $68-69$. This further reduces the opportunities for corruption. 
the minimal per acre charge), the claimant cannot be offered special deals in exchange for bribes. The Mining Law privatizes resources by allowing private entities to choose which resources are privatized and when they will be privatized. The law avoids incentive problems in allowing public land managers to choose what parcels to privatize at what times, removing an additional element of discretion from the system. ${ }^{178}$

Foregoing all compensation may seem a high price to pay for avoiding corruption, but the price is actually substantially less than it first appears. First, and this is a critically important point, the government does not forego all revenue from the mineral resources, only the revenue from their sale. Revenue from the exploitation of the resource may be taxed via income taxes on the mineral rights owners' profits or on their employees. ${ }^{179}$ Second, corruption has a corrosive effect on the ability of governments to provide services. ${ }^{180}$ Existing government institutions often expend considerable resources on corruption avoidance, including creation of inefficient procedures (e.g., requiring multiple signatures on documents), ${ }^{181}$ substituting costly public proceedings for more flexible private proceedings (e.g., government rules on procurement), ${ }^{182}$ and staffing internal affairs and audit units to attempt to uncover corruption. ${ }^{183}$ Foregoing revenue from

178 There have been abuses under federal land laws related to mineral resources. MAYER $\&$ RILEY, supra note 51, at 80-81. These abuses are not properly attributed to the Mining Law, however. For example, Mayer and Riley point to privatization of mineral resources misclassified by corrupt or incompetent officials as non-mineral land, thus allowing railroads which had been restricted from owning certain mineral land to gain title. Id. at 80 . The other examples of fraud Mayer and Riley give are the privatization under the Mining Law of land for nonmining uses, of which we approve, and avoidance of the annual work requirement, which is not related to the free access principle. $I d$. at 81 .

179 LESHY, supra note 4, at 366 (" $[\mathrm{H}]$ ardrock mineral development under the Mining Law, like any income-producing business, eventually produces some direct or indirect payment to Uncle Sam. The argument for greater revenue return is thus not an overwhelming argument for reform of the Mining Law.").

180 WORLD BANK, supra note 169 ("[Corruption] undermines development by distorting the rule of law and weakening the institutional foundation on which economic growth depends.").

181 For example, Hernando de Soto documents the need for the occupant of a home in Lima, Peru to go through 728 bureaucratic steps to obtain a legal title to a home in a validated housing settlement. Similar horrors await the majority of home occupants and farmers in Egypt, Haiti, the Philippines, and other countries with insecure real property policies. DE SoTo, supra note 121, at 192-93.

182 For example, starting a business in Australia is largely a private affair. There are only two public steps involved, taking two days to complete, at trivial cost. Compare that to the poor entrepreneur in Haiti who must go through 12 public steps, taking an average of 203 days, at a cost double the national per capita annual income. WORLD BANK, STARTING A BUSINESSCOMPARE ALL ECONOMIES (2004).

http://rru.worldbank.org/DoingBusiness/SnapshotReports/EntryRegulations.aspx (last visited July 10, 2004). For details on numerous legal procedures in many nations, see WORLD BANK, DOING BUSINESS IN 2004: UNDERSTANDING REGULATION (2004) (providing information on business regulations in various nations); see also WORLD BANK, DOING BUSINESS DATABASE, at http://rru.worldbank.org/DoingBusiness/.

183 The elaborate procedures and reporting requirements of the Sarbanes-Oxley Act of 2002, Pub. L. No. 107-204, 116 Stat. 745, in the United States are a good example of this point. See Alix Nyberg, Sticker Shock, CFO MAG., Sept. 1, 2003 (describing compliance costs \& reporting that $48 \%$ of companies surveyed will spend at least $\$ 500,000$ on compliance in 2003 ), available at 
mining claim sales means a loss of one source of revenue, but it also entails a compensating savings and increased tax revenues from other sources. ${ }^{184}$

\section{Resolving Conflicts}

Resources can be claimed by more than one party. In some instances, both competing claimants desire to exploit a resource and their dispute relates to the priority that should be given to their claim. For example, two miners may claim the same set of mineral rights. In other disputes, competing claimants have different priorities for mineral resources. A mining company may wish to develop the mineral resources, an outdoor recreation group may wish to preserve the same site for hiking, hunting, or other recreational uses, and an aboriginal group may wish to preserve the site for religious purposes while excluding recreational uses. A system of mining law must be able to resolve both types of conflicts.

The Mining Law provides a reasonably efficient means for resolving the first type of conflict. ${ }^{185}$ Disputes between competing claimants can be settled by reference to the objective criteria of who acted first. ${ }^{186}$ The Mining Law's

http://www.cfo.com/Article?article=10546 (last visited July 10, 2004).

184 As an example, assume the government must choose between a $10 \%$ net royalty on production and free access. With a $30 \%$ corporate income tax rate, a firm that earned $\$ 100,000$ from a particular mineral deposit would pay $\$ 10,000$ in royalties and $30 \%$ of $\$ 90,000$ (net profit), or $\$ 27,000$, in income taxes. Total government revenue under the royalty scheme would thus be $\$ 37,000$. Suppose that under a free access regime, the absence of the royalty induced only a $10 \%$ increase in production, which produced a proportional increase in net profits. The firm now earned $\$ 110,000$. The firm would pay no royalties but would pay $\$ 33,000$ in income taxes. The revenue loss from giving up royalties would thus be only $\$ 4,000$, not $\$ 10,000$. This example does not take into account other possible revenue increases (e.g., from income taxes on the increased labor used to increase production).

185 John Leshy argues that since their passage, the federal mining laws "have, through the millions of mining claims filed under them, promoted much litigation, generated much controversy, and occasioned much difficulty." LESHY, supra note 4, at 2. Leshy is certainly correct that there has been considerable litigation over the meaning of many of the Mining Law's provisions and claims under it. This litigation is not related to the law's allocation of rights without charge or its reliance on self-initiated privatization but to other features of the law (e.g., the distinction between lode and placer claims or the definition of "mineral lands"). We agree with Leshy that the Mining Law is a flawed implementation of the free-access principle and that the principle is a source of litigation, but we disagree with him that the remedy is to abandon the principle.

186 See Jennison v. Kirk, 98 U.S. 453, 457-58 (1878) (“The first appropriator was everywhere held to have, within certain well-defined limits, a better right than others to the claims taken up; and in all controversies, except as against the government, he was regarded as the original owner, from whom title was to be traced."). See also Andrew P. Morriss, Lessons from the Development of Western Water Law for Emerging Water Markets: Common Law vs. Central Planning, 80 OR. L. REv. 861, 877-84 (2001) (describing virtues of priority rule as a simple rule economizing on decision costs). Of course, some mining law doctrines have proven more difficult to implement than others. Other aspects of the Mining Law complicate matters. See LESHY, supra note 4, at 89-118 (detailing problems of doctrines under Mining Law). Nonetheless, the law currently does not appear to overly burden mining claimants with costs associated with challenges from other claimants. Indeed, the basic principle of priority was developed in the mining camps as part of the customary legal rules for mining law, Morriss, supra note 2 , at 599 , and the later, less cost-efficient rules arose only after the formal legal 
critics charge that it inappropriately resolves the second type of conflicts by giving mining use a priority over nonmining uses. John Leshy, for example, claims that "what is most controversial about the policy of free access is the assumption embedded within it-that mineral development is the highest and best use of any land where valuable minerals are found and may be extracted. ${ }^{187}$ If true, the Mining Law's resolution would be an inexpensive one (the mining claim always wins), but not necessarily an appropriate one since nonmining claims must sometimes be a higher use. ${ }^{188}$

Part of the problem here is that Mining Law critics do not acknowledge the incentives provided by full ownership for consideration of alternative uses. ${ }^{189}$ In part, this perception reflects a misunderstanding. The Mining Law has an absolute preference for private ownership of mineral resources over public ownership of those resources, but the law says nothing about what the private owners must do with the mineral resources once they have acquired them. Mineral resource owners are free to not exploit their property ${ }^{190}$ and have the legal ability to prevent others from doing so as they have full title to the resource and, at their option, to the surface estate as

system took a leading role in mining law. Id. at 624-25. Noted Mining Law critic John Leshy has also argued that the Mining Law provides too little security of title by making it too easy to challenge claims during the exploration phase. See Leshy, supra note 116, at 2-4. Given Leshy's hostility to mining and privatization of federal land, we are skeptical of his claim that an unspecified alternative will create more secure property rights. Setting those concerns aside, the question of whether introducing a discretionary element would enhance or reduce the security of property rights is virtually answered merely by posing the question.

187 LESHY, supra note 4, at 26.

188 GORDON \& VANDOREN, supra note 31, at para. 50 ("[T]here is nothing necessarily wrong with current practices and little economic reason to control how mineral lands are used.")

189 The choice of politics over land ownership also reveals something about the true cost of acquiring land. If, as environmental groups claim, the federal government is giving away valuable resources for nominal consideration alone, they should be able to acquire land at little cost. If, on the other hand, the mining interests are correct that the price paid to the federal government is only one of many costs to acquiring land through the Mining Law, the failure of environmental groups to acquire land suggests that those other costs (i.e., the costs of actually discovering resources) are large. See TERRY L. ANDERSON ET AL, How AND Why to PRIVATIZE PUBLIC LANDS 21 (CATO Inst. Policy Analysis No. 363, 1999) (explaining how privatized resources avoid conflicts over conflicting uses), available at http://www.cato.org/pubs/pas/pa363.pdf.

190 The Supreme Court recognized early that nonmining values can be a legitimate consideration for claimants. See United States v. Iron Silver Mining Co., 128 U.S. 673, 689 (1888). Since then a judicially-created doctrine of "good faith" has weakened the claimants' ability to consider nonmining uses. See LESHY, supra note 4, at 62-63 (describing doctrine). Although Leshy argues that the law is clear "that it was an abuse of the Mining Law to allow mining claims to provide a cover for nonmining use[s]," id. at 69 , he also documents persuasively that federal land management agencies have not taken that position during most of the Mining Law's history, see id. at 64-77 (describing how agencies generally declined to act against nonmining uses), which we suggest is evidence that the law is less clear than Leshy contends. Since the statute makes no mention of the requirement that claims be used only for mining purposes, we think the argument represents clever lawyering but not actual law. Unlike the case of water rights owners in many states, for example, mineral rights owners can "bank" mineral resources they own, choose not to develop them to protect habitat, or use the property for nonmining purposes. On the development of water rights including in-stream flow uses see Yandle \& Morriss, supra note 155, at 150-53. 
well. Ironically, when mineral rights owners do make alternative uses of their claims, they are often accused of being "speculators" ${ }^{191}$ or of inappropriate use of the mining law to privatize public property. ${ }^{192}$

There is a germ of truth to the claim of a "pro-mining" bias, but the critics are wrong about both its location and its cure. By allowing privatization of only nonwithdrawn federal lands with valuable hardrock mineral resources, federal land law prevents nonmining uses from

191 See HuMPhRIES, supra note 25, at 5 ("Critics believe that many claims are held for speculative purposes."); see also 1971 Senate Hearings, supra note 18, at 217 (statement of Mr. J. Michael McCloskey, Conservation Director, Sierra Club) ("Speculators tie-up vast areas under subterfuges."); GENERAL ACCOUNTING OFFICE, MOdERNIZATION OF 1872 Mining LAW NEEdEd to Encourage Domestic Mineral Production, Protect the Environment, and Improve Public LAND MANAGEMENT, at iii (1974) (noting that "[olpportunity for land speculation under the law is strong") [hereinafter GAO, MODERNIZATION OF 1872 MINING LAW NEEDED]. A 1989 GAO report found that relatively few claims were being actively exploited and that many claimants were holding the claims in anticipation of future mineral price increases. GENERAL ACCOUNTING OFFICE, supra note 25 , at 18 . Indeed the discovery requirement was intended to prevent speculation. HUMPHRIES, supra note 25, at 5. Despite law requiring that "no location of a mining claim shall be made until the discovery of a mineral within the limits of the claim," 30 U.S.C. $\$$ $23(2000)$, in practice the government has recognized claims based "on general indications that a mineral deposit exists, and [has] required proof of discovery only upon application for a patent unless circumstances warrant full proof sooner, e.g., mineral claims in sensitive areas" because discovery can often require substantial investment. HUMPHRIES, supra note 25 , at 5 . The periodic debates over homestead laws, discussed below, also contained some of the same arguments that now surface in the mining law debate. Interestingly for our purposes, there was great concern that the homestead laws would be used by speculators rather than by "real" settlers. As late as 1912, the Secretary of the Interior in opposing a homestead reform bill told a Congressional committee "that if we allow the public domain to pass into the hands of individual claimants-private owners-and those owners do not themselves intend to reside on and cultivate the ground, that all we have done has been to add an additional and wholly unnecessary burden to the man who is going to live on and cultivate that land, because the private owner, who obtains the land in that way, obtaining it simply for profit, will attempt to make that profit out of the real settler to whom he expects to sell." Amending the Homestead Laws: Hearing Before the House Comm. on the Public Lands, 62d Cong. 4 (1912) [hereinafter 1912 House Hearings].

192 See, e.g., GAO, MOdERNIZATION OF 1872 MINING LAW NEEDED, supra note 191, at ii (estimating that no mineral development has occurred on many claims because "the mining law provides no Federal control to insure mineral development"). Critics also argue that the Mining Law is used by those without an interest in mining to secure land for nonmining purposes. Knight, supra note 14 , at $632-33$ ("[T] he mining patent process has been repeatedly abused by individuals who have no intention to mine, but are only seeking to get title to land for a price far below fair market value."); see also 1971 Senate Hearings, supra note 18, at 224 (statement of Mr. J. Michael McCloskey, Conservation Director, Sierra Club) (noting "many spurious claims [are] filed for non-mining purposes"); GENERAL ACCOUNTING OFFICE, supra note 25, at 24-25 (noting that many claims held for non-mining purposes); LESHY, supra note 4, at 55 ("II]t has proved exceedingly difficult to ensure that the access gained to federal lands is for legitimate mineral exploration and development, as opposed to other, less legitimate uses."); Davis, supra note 1, at 901 ("The writer has seen 'mining locations'] whose only purpose was to house saloons, gambling houses, and other necessary adjuncts of a mining camp, pass unchallenged, though they were not worked as mining claims and no evidence could have been produced of discovery of valuable minerals thereon."); Sam Kalen, An 1872 Mining Law for the New Millennium, 71 U. CoLo. L. REv. 343, 352 (2000) ("The Mining Law has led to considerable abuse over the years. For example, during the first half of this century, many lands in national forests were being used under the Mining Law for non-mining purposes."). 
competing for most federal lands. The flaw lies, however, in the absence of a privatization mechanism for lands lacking valuable mineral resources.

We contend that the Mining Law offers an appropriate regime for resolving disputes within the framework of private ownership of mineral resources. The only requirement of the Mining Law historically was discovery of a valuable resource and minimal annual work on development. ${ }^{193}$ Given that activities such as maintaining boundary fences qualified under the previous annual work rule, ${ }^{194}$ now replaced by the $\$ 100$ fee, no actual mining activity or even environmentally destructive activity would be necessary to maintain and perfect a claim. ${ }^{195}$

What the Mining Law does require is documentation of the existence of a valuable resource. ${ }^{196}$ The owner of the newly privatized land is put in a position to make an informed choice about the appropriate use of the land. Not surprisingly, when valuable resources exist, landowners often choose to develop the resource. If individuals object to mining projects, however, they are free to acquire mineral resources under the Mining Law or from the owner and simply not develop the resource. There is an opportunity cost to doing so, of course, and the discovery requirement ensures that resource owners are aware of at least the approximate magnitude of those costs. Environmental organizations that oppose mining are thus free to acquire mining claims on their own, patent the claims, and not develop them. Their failure to take such an obvious step ${ }^{197}$ suggests they may not wish to face such choices. ${ }^{198}$ Where environmental organizations have faced such choices

193 See supra notes 65-79 and accompanying text. Thus even what appeared to be a promining bias (requiring work) had become so minimal by the mid-twentieth century that it no longer constituted an important bias in the law toward mineral development.

194 See GENERAL ACCOUNTING OFFICE, supra note 25, at 18 ("Activities reported as meeting the annual work requirement included maintaining boundary markers and fences, removing litter, posting signs, and checking property for vandalism and safety hazards.").

195 The current requirement for payment of the annual $\$ 100$ fee reduces this burden even more. See supra note 94 .

196 See supra note 66 and accompanying text.

197 It is obvious if the giveaway charge is true, as environmental pressure groups assert it is. If the government is really giving away vast wealth for nothing, it is irresponsible not to divert that wealth to environmentally sound purposes either by leaving the minerals in the ground or selling them to responsible developers who meet the environmental standards proposed by the groups and using the revenue to buy sensitive habitat. Thus if Interior Secretary Bruce Babbitt was really signing over $\$ 10$ billion in public assets to a mining patentee, see supra note 131 and accompanying text, why hadn't the Sierra Club or Audubon Society grabbed the resources first? $\$ 10$ billion is many times the combined budgets of all U.S. environmental organizations, allowing private habitat protection, cleanup efforts, and the like on an unprecedented scale. This back of the envelope calculation suggests that the environmental pressure groups (and former Secretary Babbitt) know that their giveaway claim is false. No doubt there is some confusion among some of the groups between the total value in the market of the output from the patented lands, which may be $\$ 10$ billion, and the profit from the patented lands, which is likely a tiny fraction of that $\$ 10$ billion. It is no giveaway to get a patent that requires billions in costs to produce billions in revenues (which are uncertain since the payoff, if any, is in the future). What Babbitt is saying is the equivalent of saying that the price of homestead land should reflect all future total revenues from that land.

198 John Leshy notes that this has happened on a small scale. LESHY, supra note 4, at 358-59 
in the past, of course, they have sometimes opted to develop natural resources or land to generate revenue to allow them to preserve alternative habitat. ${ }^{199}$

Investing in eliminating the Mining Law's "giveaway" is a rational alternative for these groups if their goal is a general attack on mining. If they prevail, they can end mining on far more land than they could ever hope to claim on their own, shifting the cost to others (such as the mining company shareholders and employees who will lose profits and wages, and the general public who will face higher prices for goods made with mineral resources and who will bear the costs of the reduced economic activity that results) rather than paying the opportunity cost themselves. The Mining Law also provides a potent fundraising vehicle for environmental pressure groups. ${ }^{200}$ If they fail, of course, the pressure groups will leave land unprotected which they could have saved. Faced with a choice between gambling on "protecting" all public land by investing in the political process to hinder mining and the sure thing of protecting some land by investing their resources in the land itself, while leaving other land open to mining, these political interest groups opted almost wholly for the former.

Consider grazing rights on public land, for example. In a thorough review of grazing practices on federal land over time, economist Gary Libecap found that insecure property rights created incentives for over-use of rangeland, ${ }^{201}$ confirming earlier findings by the United States Department of Agriculture. ${ }^{202}$ Liebcap's analysis is applicable to mineral rights. Mineral resource holders must determine when to extract a known deposit. As claims become less secure, the current rights holder has an increasing incentive to exploit the resource quickly, while he still holds the rights. This

(describing claims used for environmental purposes). He rejects this strategy, however, on the grounds that "two wrongs fail to add up to a right," and that such a strategy "could lead to political backlash that might thwart more responsible, well-considered change in the Mining Law." Id. We disagree that there are any "wrongs" in such a strategy. Even if Leshy is correct that judicial glosses on the statute effectively require more than documenting discovery, once a patent issues there is no further obligation to develop the resource. There is also a hint in the recent Environmental Working Group survey of mining claim ownership that this may be occurring. See ENVIRONMENTAL WORKING GROUP, supra note 30, at $\S 4$ (" [A] number of studies and case reports, by government agencies and the media, indicate that lands are claimed by individuals for a variety of reasons-in speculation, for private recreation purposes, or in the interest of conservation.").

199 See Dwight R. Lee, To Drill or Not to Drill? Let the Environmentalists Decide, 6 THE INDEP. REV. 217, 218-19 (2001) (describing the Audubon Society's ownership of a nature reserve where it allows oil and gas production).

200 See, e.g., EARTHWORKS, JOIN TO MAKE A DIFFERENCE!, at http://actionnetwork.org /mpc/home.html (last visited July 10, 2004) (describing need for individuals to join Earthworks Action Network to "help hold accountable one of the dirtiest industries in the world"); RICHARD \& RHODA GOLDMAN FUND, 2003 GRANTS, at http://www.goldmanfund.org/grants/03grants_env.phpx (last visited July 10, 2004) (listing a $\$ 150,000$ grant to the Mineral Policy Center for the "Campaign for Responsible Gold Mining").

201 LIEBCAP, supra note 159, at 102 ("Well defined private rights capture individual incentive and initiative for using rangeland efficiently. Further, they insure response by profit-maximizing landowners to changing market demands for range use.").

202 See id. at 24 (noting that the U.S. Department of Agriculture has "repeatedly stressed that uncertain control created pressure for immediate use of rangeland"). 
may lead to suboptimal decisions on extraction method and rate, reducing the total amount of the resource recovered ${ }^{203}$ and potentially environmentally damaging extraction techniques. ${ }^{204}$ It may also lead to adoption of techniques destructive of the surface estate.

Secure private property rights provide property owners with incentives to consider the impact of their decisions in the long run by incorporating the value of the land into the rights holders' wealth. ${ }^{205} \mathrm{~A}$ landowner who overgrazes his property, for example, will gain in the current period from the additional production but lose value from the land's decline in long term productive potential, which will be capitalized in the value of his property. ${ }^{206}$ Private landowners who hold both the surface and mineral rights thus have an incentive to consider alternative uses of the land.

Resources held by government agencies, however, are not protected by these incentives and so are vulnerable to overexploitation. ${ }^{207}$ Institutional means other than increasing the value of the land must be provided to persuade public land managers to consider alternative uses to resources they control. The Federal Land Policy Management Act of 1976 (FLPMA) ${ }^{208}$ attempts to provide this through a complex framework for balancing

203 Gary D. Liebcap \& James L. Smith, The Economic Evolution of Petroleum Property Rights in the United States, 31 J. LEG. STUD. 589, 592-93 (2002) (describing early efforts at oil recovery that wasted resources).

204 This is a goal of the Mining and Minerals Policy Act of 1970, 30 U.S.C. $\$ \S 21$ a, 1901-1905 (2000), which is intended to "lessen any adverse impact of mineral extraction and processing upon the physical environment" while improving research and technology "to promote the wise and efficient use of our natural and reclaimable mineral resources." Id. § 21a.

205 See supra note 53 , and accompanying text.

206 LIEBCAP, supra note 159, at 66 ("Among the costs they consider are the effects on future forage from current harvest (grazing) practices. To maximize the value of their land and their wealth, ranchers must continually balance the gains from heavy stocking one year with the costs from reduced available vegetation the next.").

207 See id. ("By contrast, Interior Department officials have different concerns. They cannot increase their wealth through optimal harvest strategies because they do not receive the resulting returns. Their incomes depend upon professional job positions and opportunities for advancement which are enhanced by expanding budget appropriations and staffing levels. Favorable congressional response to budget requests requires broad agency involvement in land use decisions to justify expenditure increases."); ANDERSON ET AL., supra note 189, at 7-8 (noting that politically driven decisions produce only temporary wins and that " $[\mathrm{w}]$ hen political winds shift, the battle will be fought again").

20843 U.S.C. $\$ \$ 1701-1782$ (2000). 
different land uses. ${ }^{209}$ At a minimum, the success of the FLPMA in striking an appropriate balance is open to question. ${ }^{210}$

To the extent that mineral resource rights are severed from surface rights, the mineral rights holder's incentives to mitigate harm to the surface rights or to consider the value of alternative uses of the surface estate must be provided by outside authority - either contract or regulation. Where the rights are combined and held by a single owner, however, the rights holder has a powerful incentive to make decisions on when and how to extract in light of the consequences of those decisions for both the mineral resource and the future value of the surface estate. The Mining Law's structure produces a default ownership structure that maximizes the total value of the mineral and surface resources.

The point here is not that the Mining Law will save every parcel; sometimes the value of a method of mineral production destructive of the

209 Writers seem hard-pressed to mention the FLPMA without using the word "complex." See, e.g., Richard H. Braun, Emenging Limits on Federal Land Management Discretion: Livestock, Riparian Ecosystems, and Clean Water Law, 17 ENVTL. L. 43, 59 (1986) ("FLPMA is a complex omnibus statute providing the basic framework for managing the public lands."); Morriss, Meiners \& Dorchak, supra note 51, at 564-67 (discussing regulations under FLPMA and mining). A recurring theme in criticism of the Mining Law is that it is inconsistent with the FLMPA, in particular with that statute's emphasis on fair market return and multiple uses. See, e.g., GENERAL ACCOUNTING OFFICE, supra note 25, at 23 ("FLPMA established the national policy that most public lands be managed under the principles of multiple use and sustained yield. The multiple-use principle requires federal agencies to manage their lands for the benefit of all uses, including not only mining but also those uses associated with outdoor recreation, timber, livestock grazing, and fish and wildlife conservation... [P]atenting the surface estate is not consistent with this policy because it takes the land out of federal ownership."). There are two important responses to this argument that are rarely articulated. First, there is no technical inconsistency between FLMPA and the Mining Law, since, as even the General Accounting Office conceded, the FLMPA provided that it did not apply where another statute provides an exception. Id. at 24 ("When the Congress enacted the Federal Land Policy and Management Act in 1976, it established the policy that the government receive fair market value for the use of public lands and their resources unless otherwise provided for by statute. The Mining Law of 1872 provides such an exception."). This is thus not a case where Congress passed a statute without expressly addressing a potential inconsistency with a prior statute, circumstances normally handled by principles of statutory interpretation. Second, there is no theoretical inconsistency. FLMPA provides for multiple use principles for federal land; the Mining Law provides a means of removing land from federal ownership. That removed land is no longer subject to FLMPA is precisely the point-by privatizing the land, the Mining Law makes the multiple use issue irrelevant. And the multiple use principle is needed in FLMPA because of the incentive problems in federal land ownership. Private landowners have no trouble implementing their own multiple use principles.

210 No one seems happy with federal land management. Westerners object that federal land management forecloses economic uses in favor of preservation. R. MCGREGGOR CAWLEY, Federal. Land, Western anger: The Sagebrush Rebellion and EnVIRonmental Politics 5 (1996) (noting that westerners had "a shared belief that federal managers were more sympathetic to environmental interests" than to the economic concerns that fueled the Sagebrush Rebellion). Environmental interest groups object that federal land managers allow too much economic activity at the expense of preservation. See, e.g., EARTHJUSTICE, POLICY AND LEGISLATION, at http://www.earthjustice.org/policy/index.html (last visited July 10, 2004) ("Among many anti-environmental positions, the administration supports oil and gas exploration in key wilderness areas, opposes federal clean air and water regulations, and backs increased logging and road construction in national forests.") 
surface estate will outweigh residual value from the surface estate. ${ }^{211}$ When it does so, the resource owner will not preserve or restore the surface estate. An important benefit of the Mining Law, however, is that mineral rights owners will have to consider the impact on surface estates.

A similar problem confronted timber companies and their experience shows how private land ownership can produce land use decisions compatible with environmental goals. Timber land is valued for both its timber production and for the wilderness amenities it can provide. In particular, hunting and other recreational leases offer an income stream that requires sacrificing some timber income. ${ }^{212}$ When timber companies learned how to manage their land to maximize the joint revenue stream, they did so. ${ }^{213}$ They do not do so on all land - some plots do not have the potential to generate sufficient alternate income. However, all of their land management decisions must now consider the potential opportunity costs of harvest methods that reduce the value of alternate uses.

There is indeed a problem with the Mining Law in this area: it does not privatize enough federal land with mineral resources under it. ${ }^{214} \mathrm{By}$ allowing claims to be patented without the surface estate or to remain unpatented indefinitely, the Mining Law creates too few residual claimants to make such tradeoffs. Removing some of the doctrinal accretions and statutory complications to patenting joint mineral-surface estates would improve the Mining Law's performance in this regard. ${ }^{215}$

211 The Oklahoma Supreme Court's decision in Peevyhouse v. Garland Coal \& Mining Co. 382 P.2d 109 (Okla. 1962), is often cited as an example of such a situation. The Oklahoma Supreme Court excused a coal company's remediation, required under a contract, of a strip mine on the ground that the remediation would cost $\$ 25,000$ but add only $\$ 300$ in value to the land in question. Id. at 112, 114. But see Judith L. Maute, Peevyhouse v. Garland Coal \& Mining Co. Revisited: The Ballad of Willie and Lucille, 89 Nw. U. L. REv. 1341, 1347 (1995) (suggesting that the facts of the case are different from those given in the court's opinion). The outrage over Peevyhouse that occurs in most classroom discussions stems from the violation of the explicit terms of the contract by the coal mining company. The Peevyhouses may have been foolish to trade other terms for the reconstruction provisions, but had the Oklahoma court respected their contract, they would have received what they bargained for. If their subjective valuation of the land was high enough to make them trade for reconstruction, then the court was wrong to excuse performance.

Professor Maute suggests the opinion can be defended on grounds other than that it required a wasteful expenditure. Id. at 1411. Taking the court's version of the facts as accurate, economic analysis suggests the result was incorrect. Having bargained for the reconstruction terms, however wasteful, the Peevyhouses were entitled to receive them. See ROBERT COOTER \& THOMAS UlEN, LAW AND ECONOMICS 611 (1988) ("It is difficult to imagine a more wrong-headed and outrageous opinion.... Clearly, the outcome is unfair, but it is also wildly inefficient. What is particularly galling is the majority's inaccurate and pretentious invocation of economics to justify their outrageous result.").

212 Fretwell \& Podolsky, supra note 151, at 156 ("As proceeds from recreation increased, the company's managers deliberately made the land more attractive to its visitors. Trees are now left standing for wild-animal corridors, age diversity in the forests is maintained to support more wildlife variety, and buffers are preserved along watersheds and streambeds.").

213 Id. at $155-56$.

214 We note again that there is a general question of the desirability of federal ownership of land, which we are not addressing in this paper.

215 We thus agree with Gordon and VanDoren that improving the robustness of the Mining 


\section{E. Spillovers}

Making use of one parcel of land for any particular use can generate spillover effects onto others' property, generally known in the economics literature as externalities. A system of mining law must provide a means for preventing harm to the property of others as well as for compensating those whose property is damaged by mining activity.

There are two important qualifications to this requirement, however. The first qualification is the existence of tort, property, and contract law, which already provide means of addressing some harms through generally applicable rules. ${ }^{216}$ Entering onto another's land, for example, is prohibited by the law of trespass and engaging in activities on one's own land that harm the property or person of another is prohibited by the law of nuisance. ${ }^{217}$ Contract law provides a means for property owners to incorporate additional protections against damage to their land or other activities they view as harmful by conditioning access to mineral resources on compliance with specific protective provisions or agreement to pay damages for otherwise noncompensable harms. ${ }^{218}$ The second qualification is that general environmental protection laws such as the Clean Air Act ${ }^{219}$ and Clean Water Act $^{220}$ apply to mining activities, just as they do to automobile manufacturers and sewage treatment plant operators. ${ }^{221}$ These generally applicable rules form a backdrop to any system of mining law and are available for use by individuals to seek redress for harm they may suffer.

The existence of these background legal rules means that there is no need for specific mining law provisions addressing spillovers except in circumstances where there are unique problems related to mining activities that require different or additional rules from those used in the rest of society. For example, great efficiencies are possible in the extraction of oil and natural gas from a common field if the owners of the various property

Law's privatization performance is the right approach. See GORDON \& VANDOREN, supra note 31, at para. 123 ("[T] he 1872 Mining Law serves America relatively well. It could be improved by broadening its reach to all federal land and allowing any interested party to bid for public resources.").

216 See Roger Meiners \& Bruce Yandle, Common Law \& the Conceit of Modern Environmental Policy, 7 GEo. MASON L. REv. 923, 926-46 (1999) (describing how common law protects environment). But see Frank Cross, Common Law Conceits: A Comment on Meiners and Yandle, 7 GEO. MASON L. REV. 965, 965 (1999) (disagreeing).

217 Meiners \& Yandle, supra note 216 , at $935-36$ (discussing trespass as a means of protection).

218 See Lee, supra note 199, at 220-21 (describing the Nature Conservancy's agreement to allow oil and gas production on land it owns so long as the oil company protects endangered birds on the land).

21942 U.S.C. $\S \S 7401-7671 q(2000)$.

220 Federal Water Pollution Control Act, 33 U.S.C. $\$ \S 1251-1387$ (2000).

221 See, e.g., Roger Flynn \& Jeffrey C. Parsons, The Right to Say No: Federal Authority Over Hardrock Mining on Public Lands, 16 J. ENVTL. L. \& LITIG. 249, 267-68 (2001) (discussing how Clean Water Act authority empowers BLM to reject mining operations); Leshy, supra note 116, at 14 ("Most of the major environmental regulatory laws enacted since $1969 \ldots$ apply to activities conducted under the Mining Law."). 
rights in the field coordinate their extractions. ${ }^{222}$ Many states provide specialized rules to address "unitization" of oil and gas resources to ensure that these efficiencies are realized. ${ }^{223}$ Such rules are not necessary with respect to other uses of land, however, and so are limited to oil and gas resources. Thus if and when a unique problem is identified, imposition of specialized rules may be justified. Until a unique problem is identified, however, the presumption should be that generally applicable rules suffice. ${ }^{224}$ After all, if general rules are insufficient to deal with problems that are not unique to mining, the laws must be insufficient with respect to other problems as well. Even when a unique problem is identified, care must be taken not to obstruct private solutions with legislated solutions. ${ }^{25}$

In hardrock mining the primary claim of a unique problem we have seen identified in the literature is the problem of ensuring that sites do not cause environmental damage long after they have ceased to function as productive mines. ${ }^{226}$ In this limited case, mining may potentially differ from many other activities since the long time lag between income generation and harm makes it less likely that victims will be able to recover from the tortfeasor. The straightforward solution is development of bonding provisions, which is exactly what the law has done. ${ }^{227}$ With the support of both environmental pressure groups and mining interests, BLM created bonding requirements that safeguard against future harms. ${ }^{228}$ Whether this is a truly unique problem is beyond the scope of this Article, but the approach taken appears to be the right one if the problem is indeed unique.

In one other case the general rules may be insufficient. Mining activities' frequent location near other public resources may generate harms to the public resources that the public landowner is unable to discover because of monitoring problems. Since the "public" can act only through its agents, and since public landholdings are vast, the possibility of collusion

222 See Liebcap \& Smith, supra note 203, at 595-96 (describing benefits of unitization).

223 See id. at 591 (" $[\mathrm{S}]$ tate governments have adopted legislation to force unitization via majority rules.").

224 See 1 HAYEK, supra note 122 , at 85-88 (advocating purpose-independent rules as superior).

225 See Jonathan H. Adler, Conservation Through Collusion: Antitrust as an Obstacle to Marine Resource Conservation, 61 WASH. \& LEE L. REv. 3, 26, 49-50 (2004) (describing government obstacles to private conservation).

226 See, e.g., GenERAl ACCOUNTING OFFICE, REPORT No. RCED-88-21, FEDERAL Land MANAGEMENT: LIMITED ACTION TO RECLAIM HARDROCK MINE SITES 1 (1987) (making recommendations " $[\mathrm{t}] \mathrm{o}$ help assure that federal lands damaged by mining operations are reclaimed"); GENERAL ACCOUNTING OFFICE, REPORT No. RCED-88-123BR, FEDERAL LAND MANAGEMENT: AN ASSESSMENT OF HARDROCK MINING DAMAGE 1 (1988) (estimating that "424,049 acres of federal land are currently unreclaimed as a result of hardrock mining operations").

227 See 43 C.F.R. § 3802.2 (2003) (establishing bond requirements).

228 The problem of abandoned mine sites is not an example of the problem discussed in the text of ensuring that sites do not cause environmental damage after they are closed, since current mining operations do not have responsibility (by definition) for abandoned operations. Problems at abandoned sites are a general social problem, not a problem of the current industry, and are best dealt with through general revenues. 
between public agents and private entities may require different rules for actions done near public land. ${ }^{229}$

Private landowners have a powerful incentive to monitor the condition of their land, since diminution in their land's value will directly cause a diminution in their wealth. ${ }^{230}$ Indeed, well-established rules of property law require private landowners (but generally not government landowners) ${ }^{231}$ to monitor their land for unauthorized use, allowing trespassers to gain full legal title if the landowner "sleeps" on her rights and does not evict the trespassers over time. ${ }^{232}$ Thus, for example, a private landowner who did not visit his land and so did not discover that a neighboring mine was discharging waste water onto his property would eventually be held to have lost his right to redress for the discharge. ${ }^{233}$ The incentive for the private landowner to engage in sufficient monitoring rests on the loss in wealth (through diminished land value) he would suffer as a result of his failure to monitor.

Applying the same rule to a government landowner might not be justified, however, because of the fear that the government land manager would collude with the neighbor to deliberately not notice the harm until it was too late to bring a claim in exchange for some private benefit to the manager. ${ }^{234}$ Since the manager would not suffer a loss in wealth from the damage to the public resource, there would be little incentive for the manager not to make such a trade. The criminal law might be used to

229 This is an example of a more general principle; governments are generally not estopped by their prior behavior to protect against collusion. See Fred Ansell, Comment, Unauthorized Conduct of Government Agents: A Restrictive Rule of Equitable Estoppel Against the Government, 53 U. CHI. L. REv. 1026, 1034 (1986) (" [A] no estoppel rule discourages individuals who feel aggrieved by onerous statutes and regulations from resorting to collusion with government officials, perhaps through bribery, in order to secure favorable official misrepresentations that would bind the government in future litigation.").

230 For example, the law of adverse possession is often justified on the grounds that it provides an incentive for landowners to monitor their property. See, e.g., Jeffrey Evans Stake, The Uneasy Case for Adverse Possession, 89 GEo. L.J. 2419, 2434-35 (2001).

231 See Walter Quentin Impert, Comment, Whose Land Is It Anyway? It's Time to Reconsider Sovereign Immunity From Adverse Possession, 49 UCLA L. REv. 447, 449-51 (2001) (describing rule of no adverse possession against the government and advocating changing the rule to improve monitoring of land use). But see Paula R. Latovik, Adverse Possession Against The States: The Hornbooks Have It Wrong, 29 U. MICH. J.L. REFORM 939, 945-74 (1996) (arguing that exceptions to the "no adverse possession against the state" rule have sufficiently eroded it that the general rule is that adverse possession is allowed).

232 Stake, supra note 230, at 2434-35 (summarizing "sleeping on rights" theory).

233 See, e.g., Hargraves v. Wilson, 382 P.2d 736, 743 (Okla. 1963) (upholding finding that neighbor had acquired right to discharge water onto land through adverse possession); Sbarra v. Erie R.R. Co., 68 N.Y.S.2d 478, 481 (N.Y. Sup. Ct. 1947) (recognizing such a claim exists); Hails v. Martz, 172 P.2d 52, 54 (Cal. 1946) (same).

234 Compare Fordham Operating Corp. v. County of Westchester, 370 N.Y.S.2d 977, 983-84 (N.Y. Sup. Ct. 1975) (noting no prescriptive rights to discharge water can be obtained against government landowner), and City of Benton City v. Adrian, 748 P.2d 679, 683 (Wash. App. 1988) ("Regardless of how the evidence is construed, title by adverse possession, or an easement by prescription, cannot be acquired to property held by a municipal corporation for public purposes in its governmental capacity."), with the cases cited in note 233 , supra. 
provide some incentive to the manager, but the costs of such an approach limit its usefulness. ${ }^{235}$

Special rules aimed at mining spillovers might also be justified if mining activities create a class of harms that are sufficiently harmful in the aggregate to warrant societal action but insufficiently harmful to any particular individual to motivate individual action. An activity that released extremely low levels of a substance which caused no harm locally but whose general buildup in the atmosphere over time caused substantial harm is an example of such a spillover. ${ }^{236}$ of course many activities that cause widespread harm also cause local harm; emission of toxic chemicals into a stream, for example, increases the overall level of the chemicals in the oceans eventually but also causes, in most cases, severe harm to the local body of water into which the chemicals are released. The specific harm is often enough, when properly specified property rights exist, to induce legal action to stop the emissions, and so prevent both the large scale and the local harms even if there are also spillover effects. ${ }^{237}$

The problem with the spillover analysis is that it has no logical stopping point. For example, many advocates of nationalization of mineral resources in developing countries in the 1970s argued that mining companies "should expect to be required to respond positively to the social, political and economic needs of host nations." 238 These needs were spillovers that justified nationalization. Caution must therefore be used to avoid relying too heavily on spillover arguments. The assertion that spillovers exist does not, without more, require special rules for a particular activity. The general framework of property, tort, and contract law that governs relations between property owners should be sufficient to handle such matters unless unique circumstances are identified. To the extent unique problems exist in mining, however, the Mining Law's privatization system does not provide a means of solving such problems and may make them worse by fragmenting property rights and so raising the transaction costs of negotiating a solution.

\section{F. Comparing Solutions}

How does the free access principle compare with the alternatives of a leasing or royalty program? Table 1 provides a summary of our conclusion with respect to these issues. Although it is not the best on all five criteria,

235 See Geraldine Szott Moohr, An Enron Lesson: The Modest Role of Criminal Law in Preventing Corporate Crime, 55 FLA. L. REv. 937, 968 (2003) (arguing criminal law has limited ability to deter bad behavior by corporations and their employees).

236 The impact of chlorofluorocarbons formerly widely used in aerosol cans and air conditioners is a common example of this category. But see Bruce Yandle, Grasping for the Heavens: 3-D Property Rights and the Global Commons, 10 DUKE ENVTL. L. \& PoL'Y F. 13, 37-40 (1999) (examining CFC issue and concluding that property rights solutions are possible).

237 See Andrew P. Morriss \& Roger E. Meiners, Principles for Pesticides, 28 WM. \& MARY ENVTL. L. \& POL'Y REV. 35, 60-61 (2003) (advocating solving local problems as means to solving larger problems).

238 OTTO \& CORDES, supra note 48 , at $1-45$. 
free access (and so the Mining Law) scores sufficiently well overall that our incentive story rings true.

We now turn to testing our theory with three issues: a comparison with the homestead laws, consideration of both of the major changes that have been made in the Mining Law (the withdrawal of some resources and some land from its coverage), comparison with state policies on mineral resources, and the major criticisms of the Mining Law.

Table 1: Summary of Incentive Effects

\begin{tabular}{|c|c|c|c|c|}
\hline & \multicolumn{2}{|c|}{ - More property rights } & \multicolumn{2}{|c|}{ Fewer property rights• } \\
\hline & Free Access & Auction & Leasing & $\begin{array}{l}\text { Public } \\
\text { Ownership }\end{array}$ \\
\hline $\begin{array}{l}\text { Incentive } \\
\text { to Locate }\end{array}$ & $\begin{array}{l}\text { Award of } \\
\text { entire bundle } \\
\text { of rights } \\
\text { provides } \\
\text { maximum } \\
\text { incentive to } \\
\text { locate }\end{array}$ & $\begin{array}{l}\text { Incentive } \\
\text { reduced by } \\
\text { need to pay } \\
\text { transfer fees }\end{array}$ & $\begin{array}{l}\text { Incentive } \\
\text { reduced by } \\
\text { need to pay } \\
\text { transfer fees }\end{array}$ & $\begin{array}{l}\text { Dependent upon } \\
\text { public agency's } \\
\text { offering of a } \\
\text { reward }\end{array}$ \\
\hline $\begin{array}{l}\text { Incentive } \\
\text { to Develop }\end{array}$ & $\begin{array}{l}\text { Residual } \\
\text { claimant } \\
\text { status induces } \\
\text { appropriate } \\
\text { choices }\end{array}$ & $\begin{array}{l}\text { Residual } \\
\text { claimants } \\
\text { created by } \\
\text { pressure to } \\
\text { develop from } \\
\text { need to fund } \\
\text { payment }\end{array}$ & $\begin{array}{l}\text { Residual } \\
\text { claimants } \\
\text { created by } \\
\text { pressure to } \\
\text { develop from } \\
\text { need to fund } \\
\text { payment }\end{array}$ & $\begin{array}{l}\text { Residual } \\
\text { claimant status } \\
\text { depends on } \\
\text { whether agency } \\
\text { keeps the } \\
\text { revenue from any } \\
\text { development of } \\
\text { the resources. }\end{array}$ \\
\hline Corruption & $\begin{array}{l}\text { Lack of } \\
\text { discretion } \\
\text { reduces } \\
\text { opportunity } \\
\text { for corruption }\end{array}$ & $\begin{array}{l}\text { Discretion } \\
\text { creates } \\
\text { opportunity } \\
\text { for corruption }\end{array}$ & $\begin{array}{l}\text { Discretion } \\
\text { creates } \\
\text { opportunity for } \\
\text { corruption }\end{array}$ & $\begin{array}{l}\text { Discretion } \\
\text { creates } \\
\text { opportunity for } \\
\text { corruption }\end{array}$ \\
\hline $\begin{array}{l}\text { Conflicts } \\
\text { Over Use } \\
\text { \& Long- } \\
\text { Term } \\
\text { Manage- } \\
\text { ment }\end{array}$ & $\begin{array}{l}\text { Clear rule + } \\
\text { residual } \\
\text { claimant } \\
\text { creates } \\
\text { incentive to } \\
\text { maximize long } \\
\text { term value } \\
\end{array}$ & $\begin{array}{l}\text { Clear rule }+ \\
\text { residual } \\
\text { claimant } \\
\text { creates } \\
\text { incentive to } \\
\text { maximize long } \\
\text { term value } \\
\end{array}$ & $\begin{array}{l}\text { Clear rule + } \\
\text { temporal } \\
\text { limitation on } \\
\text { interest creates } \\
\text { incentive to } \\
\text { develop fast }\end{array}$ & $\begin{array}{l}\text { Dependent on } \\
\text { being able to } \\
\text { control agency } \\
\text { via statutes, } \\
\text { regulations, etc. }\end{array}$ \\
\hline $\begin{array}{l}\text { Environ- } \\
\text { mental } \\
\text { Spillovers }\end{array}$ & $\begin{array}{l}\text { If problems } \\
\text { unique to } \\
\text { mining exist, } \\
\text { will not solve }\end{array}$ & $\begin{array}{l}\text { If problems } \\
\text { unique to } \\
\text { mining exist, } \\
\text { will not solve }\end{array}$ & $\begin{array}{l}\text { Agency can } \\
\text { modify lease } \\
\text { terms as learn } \\
\text { of unique } \\
\text { problems }\end{array}$ & $\begin{array}{l}\text { Unclear - agency } \\
\text { may opt to } \\
\text { protect } \\
\text { environment } \\
\text { (e.g., EPA) or } \\
\text { develop (e.g., } \\
\text { Army Corps of } \\
\text { Engineers) }\end{array}$ \\
\hline
\end{tabular}




\section{TESTING THE THEORY}

In the previous section, we showed the advantages of the incentive effects of the Mining Law. In this section we examine some of the counter examples cited by Mining Law critics. The first is a general attack based on the Mining Law's association with other land disposal statutes, most notably the homestead laws. Does the federal government's abandonment of those laws mean the Mining Law should be abandoned too? The second and third are based on the narrowing of the scope of the Mining Law in the more than 130 years since it was passed. Both land and minerals have been withdrawn from the Law's coverage. Does this narrowing reveal problems with the Mining Law that would warrant its termination? Finally, state governments and private landowners do not "give away" the mineral rights to their land. Does this suggest that the federal government should not do so either? We examine each of these arguments in turn.

\section{A. Mining and Homesteading Compared}

As critics of the Mining Law consistently point out, ${ }^{239}$ the 1872 statute was one of a series of nineteenth century laws aimed at transferring publicly held resources to private ownership. ${ }^{240}$ These laws included the homestead laws (which led to the privatization of almost 214 million acres); railroad grants (including approximately 129 million acres); grants to states for educational purposes (over 73 million acres); and "swamp" grants to states (over 63 million acres). ${ }^{241}$ These programs were ended long ago. The most important of these for the Mining Law debate are the homestead laws, since they mirrored the Mining Law's grant of resources to individuals. Although the homestead laws have sometimes been viewed favorably by public land historians, ${ }^{242}$ the consensus is now largely negative. ${ }^{243}$ Congress distinguished the Mining Law from the homestead laws. Even as support for homesteading waned, however, political support for the Mining Law remained strong. During the 1934 debates over the Taylor Grazing Act which "effectively ended homesteading," for example, there was repeated acknowledgement that the new law would not alter the Mining Law, including explicit language in the statute preserving the Mining Law. ${ }^{244}$ This

239 See, e.g., John D. Leshy, The Babbitt Legacy at the Department of the Interior: A Preliminary View, 31 ENVTL. L. 199, 223-24 (2001) ("Babbitt relentlessly promoted reform lof the Mining Law], understanding that it not only benefits the environment and the taxpayers but also carries the powerful symbolism of burying, at the dawn of the twenty-first century, the last important survivor of nineteenth century ... public land policies.").

240 See, e.g., Knight, supra note 14, at 626 ("Viewed against this backdrop [of the homestead laws and land disposal policies], the Hardrock Act made sense.").

241 Anderson \& Martin, supra note 99, at 908-09.

242 Id. at 913 ("Most public domain historians seem convinced that the land grant policy was a boon to the economic development of the frontier and had desirable distributional effects (that is, a form of highly equalitarian resource redistribution). ${ }^{\text {) }}$.

243 See infra sources cited in notes $247,249,273$, and 274.

244 Charles Wallace Miller, JR., Stake Your Claim! The Tale of america's Enduring MINING LAWS 200-02 (1991). 
could be the result of special interest lobbying rather than a recognition of the differences between the Mining Law and the homestead laws. What does the record of the homestead laws tell us about which explanation of the Mining Law's persistence is correct?

\section{Giving Away Resources}

One of the crucial arguments about homestead law bears a strong similarity to arguments about the desirability of the Mining Law: Did the federal government release land from the public domain at the rate to maximize social welfare ${ }^{245}$ The general conclusion is that properly constructed auctions would have done so but that the homestead system did not. ${ }^{246}$ Homestead laws thus precluded the federal government from raising needed revenue and led to premature settlement of the frontier. This mirrors the critics' view of the Mining Law as privatizing too much too soon at too low a price. To assess this argument we need to examine why the federal government adopted a policy of giving away resources.

The original land disposal policy of the federal government emphasized revenue generation, not privatization, as the primary goal. ${ }^{247}$ For example, Albert Gallatin, an important figure in early U.S. government who served in Congress and as Jefferson's Secretary of the Treasury during the Louisiana Purchase, ${ }^{248}$ argued in a debate in the House of Representatives over creating a public land office to sell off federal lands that "extinction of the curse of the country, the Public Debt" was of great importance ${ }^{249}$ and President George Washington urged sale of federal lands to "save the necessity of burthening [sic] our citizens with new taxes for the extinguishment" of the public debt. ${ }^{250}$ Early federal legislation emphasized the sale of public lands at auction to increase short term revenue and Congress regularly authorized vigorous measures to discourage and remove squatters on federal lands. ${ }^{251}$ Auction rules, such as minimum prices above

245 See R. Taylor Dennen, Some Efficiency Effects of Nineteenth-Century Federal Land Policy: A Dynamic Analysis, 51 AGRIC. HIST. 718, 727 (1977) ("[T]here is some optimal path of releasing land from the public domain and bringing it into production which will maximize the value of output. Releasing land more quickly will reduce output, as will releasing land too slowly."). Of course, we can evaluate whether a given policy was "optimal" from both an ex ante and an ex post perspective. It is impossible to know with certainty what the optimal policy is ex ante since uncertainties abound.

246 See id. at 727 (noting that an auction system is optimal).

247 Douglas W. Allen, Homesteading and Property Rights; Or, "How the West Was Really Won", 34 J.L. \& ECON. 1, 7 (1991) ("The initial goal of releasing public lands was to generate revenue.").

248 For biographical information on Gallatin, see U.S. DEP'T OF THE TREASURY, HISTORY OF THE TREASURY: SECRETARIES OF THE TREASURY: ALBERT GALLATIN, at

http://www.ustreas.gov/education/history/secretaries/agallatin.html (last visited July 11, 2004).

249 Mark T. Kanazawa, Possession is Nine Points of the Law: The Political Economy of Early Public Land Disposal, 33 EXPLORATIONS IN ECON. HisT. 227, 236 (1996).

250 Id.

251 Id. at 237. 
the transaction cost of running the auction, were designed to increase revenue. ${ }^{252}$

Despite this, by 1830 Congress had effectively opened the federal lands to claims based on occupancy that produced little revenue, with a general preemption act passing in 1830 after a series of special preemption acts in the preceding years had opened numerous areas of public lands to squatters' claims. ${ }^{253}$ After 1862 , essentially all federal land disposal was done through grants rather than sales, and these grants ultimately disposed of more than twice as much land as was sold. ${ }^{254}$

The development of the privatization rationale after the government was already successfully raising revenue through land sales raises a crucial point. As Professor Douglas Allen noted, "On the surface, the U.S. experience is puzzling because the federal government began disposing public land through auctions and other price mechanisms before it established the practice of homesteading." ${ }^{255}$ This sequence of events suggests that non-price allocation of resources cannot be dismissed as merely a bad idea from the past. Non-price allocation of public resources was an innovation-an institutional response to something. Whether the something demanded was the set of features we discussed above or something else is an empirical question that requires closer examination for a definitive answer. Nonetheless, the sequence of events shows that nonprice allocation of federal land was an attempt to deliver something that auctions and other forms of sale did not provide. It might be that non-price allocation served the types of purposes we outlined earlier or that Congress switched from selling assets to giving them away to reward specific interest groups.

\section{Was Homesteading Rent-Seeking?}

Professor Mark Kanazawa offers a rent-seeking explanation for the adoption of non-price allocation of land. He argues that the squatters' activities in the period before the federal government abandoned revenue generation as a goal both created political pressures for recognition of their rights and changed the economics of federal land auction process. ${ }^{256}$

252 Dennen, supra note 245 , at 728.

253 Allen, supra note 247, at 8; Kanazawa, supra note 249, at 241 . Proponents of preemption argued that preemption would not harm federal revenues because auction prices were not significantly above the small fees charged squatters to regularize their titles, that so many particular preemption provisions had passed that a general rule would simply regularize an existing practice, and that creating property-holding citizens was a public good. Id. As a result, the federal government gave up "billions of dollars, even at 1870 s price levels." Anderson \& Martin, supra note 99 , at 910 .

254 Anderson \& Martin, supra note 99, at 908. Many of the grants to states and railroads were indirect revenue measures. The railroad grants were intended to induce and fund railroad construction and grants to states often required subsequent sale of the granted lands. See Paul Wallace Gates, The Homestead Laws in an Incongruous Land System, 41 AM. HIST. Rev. 652, 658-59 (1936).

255 Allen, supra note 247 , at 2.

256 Kanazawa, supra note 249, at 228. 
Squatters "disrupted the operation of the local land auctions, thus reducing auction revenues and making adoption of preemption less unacceptable to its (mostly eastern) opponents in Congress." 257 Kanazawa finds empirical support for his explanation in a statistical examination of congressional votes on the 1830 preemption act. ${ }^{258}$ For example, he finds that support for preemption in the House depended on the benefits a congressman's district would receive, rather than on a general sectional disagreement (such as northeastern states against southern and western states). ${ }^{259}$

Similarly, Professors Gary Anderson and Dolores Martin argue that a coalition of political interest groups interested in ensuring the continuation of tariffs from which they benefited and congressmen anxious to spend federal resources "off budget" contributed to the transition from auctions aimed at revenue generation to "free" land through the homestead system. ${ }^{260}$ Nineteenth century federal revenues came largely from land sales and tariffs. As the potential revenue from land sales grew, those interested in preserving the advantages of tariffs for domestic firms over foreign competitors supported reduction of land revenues. ${ }^{261}$ Nineteenth century federal budgets also routinely ran significant surpluses, making it difficult for Congress to justify bringing in additional revenue. Being able to "spend" federal resources by giving away non-cash assets such as land, rather than selling the land and then spending the money, enabled politicians to increase transfers of resources. ${ }^{262}$

Are there similar explanations of the Mining Law that suggest that it was the result of similar political pressures? If the Mining Law was the result

257 Id. The revenue reduction/political pressure theory rests heavily on recognition of the "significant cost of enforcing federal property rights to the public lands." Id. Like the land given away through the homestead laws, mineral rights were located in the west, often far from any sources of federal authority. See Morriss, supra note 2, at 593-95. The only federal authority that was present was usually the military, which had other priorities. Doyce B. Nunis, Jr., Historical Introduction to George Frederic Parsons, From MEXICAN Days to the GOLD RuSH, at lii (Doyce B. Nunis, Jr. ed., 1993) ("Unfortunately, the military government [in California in 1848-49] proved unequal to the task of establishing, let alone enforcing, law and order. It simply did not have the manpower."). Federal authority is now much cheaper to project onto public lands in the West. It is not cost free, however. See CAWLEY, supra note 210, at 71-91(describing anger of western residents over federal land management policies).

The costs of enforcing federal authority were large and thus were a good reason to adopt the Mining Law's approach. Is the reduced cost of projecting federal authority a reason to abandon the Mining Law? Only if the costly-to-enforce rationale is determinative. As we have outlined a case for the Mining Law above that does not depend on the original motivation, the absence of that motivation is not a sufficient argument against the law.

258 Kanazawa, supra note 249 , at 241-47.

259 Id. at 244 ("[P]ublic lands congressmen were probably influenced more strongly by the local level of squatting activity than by whether they represented a public lands state.") The passage of the general homestead laws in the 1860 s was due to the absence of the Southern states from Congress; the Southern states had opposed lowering the price of land for free labor. 4 WOOdROW WILSON, A HisTORY OF THE AMERICAN PEOPLE 214-15 (1906).

260 Anderson \& Martin, supra note 99, at 913-19.

$261 \mathrm{Id}$. at 917 ("There is strong evidence that this substitutability [of land sale and tariff revenue] may have been a significant factor in the demise of the system of revenue-maximizing land sales.").

262 Id. at $916-17$. 
of political dealmaking, that would suggest the need for additional skepticism over any claimed advantages it might have. The miners' existing implicit rights to mineral resources certainly influenced Congress in deciding to recognize the rights. Of course, not all political deals produce bad outcomes-a principle that would eliminate virtually all legislation throughout history-but an explicit role for interest group politics should make us careful in assessing resulting legislation.

The Anderson and Martin theory can help explain support for the disposal statutes generally but does not question the underpinning of disposal statutes open to all. Railroad grants were obvious examples of the benefits of "off-budget" spending from a special interest perspective, but recognizing mining claims produced benefits for a more diffuse class in a highly fragmented, competitive industry. Moreover, while the off-budget nature of recognizing of mining claims may have made it easier to agree to the Mining Law, the major reason for agreement was that the "facts on the ground" had been established by the various gold rushes. ${ }^{263}$

Moreover, the rent-seeking story is not the only plausible explanation of homesteading. Professor Douglas Allen, for example, "focuses on the state's role as contract enforcer" to explain the homestead laws. ${ }^{264} \mathrm{He}$ argues that "the land policies were efforts to 'hire' settlers to reduce the costs of enforcement" against Indian land claims. ${ }^{265}$ Homesteading was "a substitute for direct military force" and a means "to mitigate the costs of violence." 266 Land claims in the west were contested by numerous well-armed Native American tribes. The existence of contested claims could produce violence, however, only if there was uncertainty over which side would prevail in armed conflict. By luring settlers west in greater numbers and concentrating them in particular areas by manipulating the opening of lands to homesteading, the federal government was able to use settlers to change Native Americans' perception that they could prevail. ${ }^{267}$ Professor Allen's analysis recognizes this principle: "Despite the diversion of resources, the fraud, and the lack of completion, [the homestead laws] did provide further incentives to occupy what was then enemy territory." 268

It thus seems likely that homestead laws in particular and land disposal laws in general were the result of a mix of causes. The rent-seeking stories that attempt to explain the creation of the homestead laws rest on conditions that did not exist with respect to mineral rights. Moreover, while the benefits to individuals and interest groups surely influenced the legislators voting on these statutes, both homestead laws in particular and land disposal laws generally served multiple purposes. Most importantly, what matters today is not the intent of the statute but the incentives the

263 See supra notes 109-114 and accompanying text.

264 Allen, supra note 247, at 2.

265 Id.

266 Id.

267 Id. at 5.

268

Id. at 11 . 
statute created. The rent-seeking stories about the homestead laws' passage thus do not provide a valid argument against the Mining Law.

\section{Problems with Homesteading}

In recent years, the homestead laws have come under criticism for promoting inefficient resource use. For example, one commentator notes that " $[t]$ he frontier era is well behind us, the West is settled, and the federal policy of giving away western land fell by the wayside decades ago with the effective demise of the homestead laws." 269 Homesteading induced settlement of the west "too soon." Benjamin Hibbard, a prominent historian of public lands, summarized the problem: "All in all, the homestead acts served to spread population too rapidly over a wide stretch of territory.... Land was being used too soon and in too great quantities in relation to other occupations and developments. ${ }^{270}$ As a result, most historians examining the issue concluded that federal land disposal policies harmed the U.S. economy by reducing output through diversion of resources into agriculture. ${ }^{271}$ Since homestead laws were bad, the critics argue, the Mining Law must also be bad, since both were resource disposal laws that allocated federally-owned resources through non-price mechanisms. ${ }^{272}$

The Mining Law critics have half of a good argument here. There were serious incentive problems with the homestead laws. For example, the lack of a price mechanism for federal land open to homestead entry caused a race for the assets that dissipated the economic rents settlers acquired by not having to pay market prices for their land. ${ }^{273}$ The key to the rentdissipation analysis is that homestead laws provided valuable assets in exchange for a willingness to undergo the hardships of settlement. Because the first to settle got the resource, a successful claimant had to settle before the settled region was economically viable. ${ }^{274}$

As a result, Professor Richard Stroup argues that by substituting settlement for a cash price, homestead laws "bought" the misery the homesteaders endured to prove their claims. ${ }^{275}$ By distributing land based on

269 Knight, supra note 14 , at 626 ("Homesteading gets no respect. Both historians and economists alike find only bad things to say about it."); see also Allen, supra note 247, at 1.

270 Dennen, supra note 245 , at 731 .

271 Id. at 718.

272 This argument is made mostly by implication in the critical literature but we have done our best to flesh it out here.

273 Terry L. Anderson \& Peter J. Hill, The Race for Property Rights, 33 J.L. \& Econ. 177, 195 (1990) (" $[R]$ ents were dissipated through resource expenditures under squatting and homesteading.").

274 Richard L. Stroup, Buying Misery with Federal Land, 57 PuB. CHOICE 69, 71 (1988) ("Willingness to endure the added pains of settlement ahead of the frontier-before the transportation network, supplies, and markets for farm products were within reach of the homestead-was rewarded by land claims which later became valuable.").

$275 \mathrm{Id}$. at 70 (" $[\mathrm{C}]$ ompared to a series of auctions, or the policy of selling the land at a minimum price, the Homestead policy not only failed to gain revenues for the federal treasury: this particular form of public lands disposal, by inducing very early settlement, unintentionally 'bought' huge amounts of pioneer suffering."). 
competition over who would settle first, the homestead laws gave land to the settlers most optimistic about the time when an area would become economically viable to farm, since optimistic settlers would be willing to settle an area before less optimistic settlers. ${ }^{276}$ (A similar phenomenon exists in any auction - the winning bidder is the most optimistic about the value of the good being auctioned.) $)^{277}$ Stroup notes that by auctioning land based on willingness to suffer deprivations, rather than based on willingness to pay money, the homestead laws eliminated the offsetting gain to the seller (in this case, the federal government) of receiving the optimistic buyer's payment. ${ }^{278}$ Stroup's analysis raises an important warning about using nonprice competition to award resources: "It is difficult to give away value systematically, since nonprice competition for the value, unlike competition in exchange (bidding, for example), will tend to waste resources up to, or even past the point where the waste is equivalent in value to the rents sought." 279

This is a potentially serious problem for our analysis. If a similar effect exists under the Mining Law, it would cause a waste of resources that would likely dissipate the gains from the incentive effects we noted earlier. There are three important differences between the homestead laws and the Mining Law, however, that make this only half of a good objection. First, the Mining Law lacks the provisions Stroup notes that "charged" homesteaders in misery. The Mining Law required only that claimants perform the minimal effort of $\$ 100$ annual work (now payment of the $\$ 100$ annual fee) and that the claimant discover valuable resources. There is no requirement to live on a claim while proving it. Even the $\$ 100$ annual work requirement, which meant more days of work in the nineteenth century rather than the few hours work it required in the late twentieth century, was a relatively small burden and one linked directly to the reason for the claim: locating mineral deposits. The Mining Law managed to escape "buying misery" through its institutional design-perhaps one reason it has persisted while the homestead laws have been repealed.

Second, to the extent the Mining Law causes a race for resources, the race is conducted through efforts at determining where resources might be found. Such a race differs from the homestead race in at least one critically important way: it is a productive race. One wins by investing in locating valuable resources rather than by suffering through harsh winters with

276 Id. at 74-75; see also Dennen, supra note 245, at 729 (describing the decision-making process of a homesteader); P.J. Hill, What's So Special About the Farm?, in AGRICULTURAL POLICY AND THE ENVIRONMENT 1, 9 (Roger E. Meiners \& Bruce Yandle eds., 2003) (" $[\mathrm{A}] \mathrm{s}$ settlers moved across the West, the homestead acts proved unsuitable for the arid regions, and enormous hardship and suffering resulted. . . Failure rates were high in many localities, reaching 80 percent of original entries in parts of Montana.").

277 See generally RiCHARD H. THALER, THE WinNER'S CurSe 1-2 (1994) (explaining this phenomenon).

278 Stroup, supra note 274 , at 75 ("Had the homesteading process been replaced by a simple auction, some of the same people would have overbid--but their cash losses would have been matched by identical cash gains to the seller (the U.S. Treasury).").

$279 \mathrm{Id}$. at 76. 
inadequate food. The rents are dissipated through activities that benefit society, not by unproductive competitions or by transfer payments to the government. ${ }^{280}$

Third, the homestead laws required claimants to bring the land into production while the Mining Law does not. The premature production induced by the homestead laws was an important cause of rent dissipation. ${ }^{281}$ It is possible that the investment in locating will be too large ${ }^{282}$ If the Mining Law has problems, however, they are different from the homestead laws' problems. The analogy does not provide a valid argument against the Mining Law.

The homestead law debate does suggest one reason why the Mining Law is superior to the homestead laws. Professors Terry Anderson and P.J. Hill compared homesteading to land sales to speculators. ${ }^{283}$ They found that "[i]t was the speculators who undertook socially efficient action by not doing anything on the land" until much later than the squatters and homesteaders. ${ }^{284}$ By holding land out of production, the speculators avoided the rent dissipation caused by putting the land into production too early. The Mining Law does not require production; indeed a frequent complaint against the Mining Law is that it allows "speculators" to acquire mineral rights. ${ }^{285}$ In this regard, the Mining Law avoids the incentives for wasteful behavior created by the homestead laws and instead provides incentives for socially efficient behavior. Moreover, unlike homesteading where every marginal productive parcel of land was occupied at least a century ago, prospecting for minerals continues to be a productive activity today; the mining lands were not dispensed in one shot to ill-informed homesteaders. We thus conclude that the homestead law analogy does not provide an adequate reason to reject the free access principle for hardrock minerals.

280 Chile's successful telecommunications privatization efforts demonstrate the importance of basing privatization allocations on a factor other than transfer payments to the state. One of the authors (Morriss) saw a memorable presentation by a Chilean telecommunications regulator at a conference on NAFTA. After presentations by American and Canadian regulators on the suitability of NAFTA's provisions for "advanced" telecommunications markets like the U.S. and Canada but not for "emerging" markets like Chile and Mexico, the Chilean participant produced his Chilean cellular phone and explained the advanced features it provided, all of which were unavailable in the U.S. and Canada. The Chilean speaker attributed the difference to the means of allocating licenses, noting that in Chile licenses were auctioned based on the amount the bidder was willing to invest in the network rather than on the amount the bidder was willing to pay to the government, as in the U.S.

281 Anderson \& Hill, supra note 273, at 182.

282 See id. at 180 (" $[\mathrm{O}]$ ne of the most important costs of settling the frontier [was that] of defining and enforcing property rights.").

283 Id. at $187-95$.

284 Id. at 191.

285 See supra note 191 and accompanying text. 


\title{
B. Resource Withdrawals
}

Two sets of resources have been withdrawn from the Mining Law's coverage: fuel minerals such as coal, gas, and oil, ${ }^{286}$ and "common variety minerals" such as sand, gravel, stone, and cinders. ${ }^{287}$ Removing these minerals from the land now requires payment to the government ${ }^{288}$ and discovery of the resources within a fixed time period. Why were these removed from the Mining Law's coverage and what does their removal tell us about the Mining Law?

For fuel minerals, the explanation is straightforward: technical reasons make the Mining Law's structure unsuitable, diminishing the benefits of coverage to the miners. In addition, there were powerful interest groups who benefited from withdrawing fuel minerals from privatization. The diminished benefits flow from the "common pool" nature of oil deposits. As a result, the claim size limit of 20 acres was also poorly suited to oil, because larger acreage was needed for efficient production. ${ }^{289}$ The small claim size allowed under the Mining Law, for example, made oil companies vulnerable to speculators who filed claims near the oil companies' claims. ${ }^{290}$ As a result, oil lands were often temporarily withdrawn from the Mining Law's coverage during the early 1900 s to assist oil interests in fending off speculators. ${ }^{291}$ Moreover, the scope of the conflict over the rule was kept small by the belief

286 Mineral Leasing Act of 1920,30 U.S.C. $\S \S 181-193,195,201-209,211-214,223-229,241$, 251, 261-263 (2000). Coal has never been covered by the Mining Law; it is governed under a separate and complex statutory scheme we do not discuss in this article for reasons of space. We plan to address it in future work.

287 Materials Act of 1947,30 U.S.C. $\$ \S 601-604$ (2000); Surface Resources Act, 30 U.S.C. $\S 611$ (2000). For further information on the definition of "common variety minerals," see Ethel R. Alston, Annotation, What Constitutes Common Varieties within the Meaning of Federal Statute, 38 A.L.R. FED. 456 (1978). Congress has rejected at least one attempt to withdraw particular minerals from the Mining Law. Interestingly, this rejection concerned a resource whose rapid discovery and development was seen as vital to national security. Congress rejected an attempt by President Harry Truman to withdraw uranium lands from the Mining Law in 1946:

\begin{abstract}
Congress could have endorsed Truman's proposed policy and provided direct government mining of uranium, either by the military or by the new civilian Atomic Energy Comunission. Or Congress could have provided a contract system with industry to mine uranium, or even a lease system, since that method had been used successfully for oil and gas since 1920. Instead, Congress specifically restored uranium to the applicability of the Act of 1872 , reversing the Executive Orders. Such a reversal is all the more remarkable since a strongly Democratic Congress united with the Republicans against a Democratic President and Secretary of the Interior on this sole aspect of the Act of 1946 .
\end{abstract}

MilLeR, supra note 244, at 219. The result was a mineral rush similar to the 19 th century gold and silver rushes. Id. at 222-28. For a discussion of current issues concerning uranium mining, See NAT'L RESEARCH COUNCIL, supra note 45 , at $145-47$.

288 Davis, supra note 1 , at 907.

289 ClAWSON, supra note 171, at 128 (noting "cases of outright warfare" among claimants); MAYER \& RILEY, supra note 51, at 164-65 (noting that oil interests sought to restrain overproduction caused by the race induced by the Mining Law).

290 See MAYER \& RILEY, supra note 51, at 158 (“[T]he [Mineral Leasing Act] was an attempt to restructure the competitive character of oil production in California.").

291 MULLER, supra note 244, at 181. 
(which persisted until after passage of the 1920 law) that oil deposits were located only in California. ${ }^{292}$

A second crucial difference between oil and gas and hardrock minerals is the timing of the resolution of the uncertainty. As a BLM official summarized, "The only thing coming up out of the hole [an oil well] besides water is oil and gas .... When you take a shovelful of highly enriched ore, it is a whole different picture." ${ }^{293}$ There is more uncertainty about the production value of a mineral find - even after it is discovered - than there is for oil and gas fields. ${ }^{294}$ Estimating the value of an oil or gas find is thus more likely to produce an accurate estimate than for a hardrock deposit, making auctions easier to structure because the value of the resources both more comparable to other claims and more certain. ${ }^{295}$ Thus, the technical story is that by changing the rules, the value of mineral resources was increased because the new rules facilitated technically optimal extraction techniques. The expanded pie could be shared with the government through royalty and lease payments and still leave the oil companies with an absolutely larger, but relatively smaller, piece of the pie.

The second part of the story follows the rise of a powerful interest group that wanted fuel minerals removed from Mining Law coverage. The military sought to secure a domestic supply of oil during the 1910s, and the chaos produced by the technical problems with the application of the Mining Law to fuel minerals led to demand to protect fuel mineral lands through withdrawals. ${ }^{296}$ The recognition of the military importance of fuels was accompanied by fears that U.S. supplies were being depleted. ${ }^{297}$ In 1909 , for example, President William Howard Taft withdrew land to preserve oil for federal use. ${ }^{298}$ Withdrawals continued through World War I, aimed at protecting oil reserves for military use. ${ }^{299}$ There was thus an important interest group seeking withdrawal of the reserves.

\footnotetext{
292 MAYER \& RILEY, supra note 51, at 157.

2931990 Senate Hearings, supra note 4, at 19 (statement of Mr. Cy Jamison, Director, Bureau of Land Management).

294 Id. at 24.

295 One witness to the 1990 Senate Hearings noted the following:
}

[T] he real difference [between oil and gas and hardrock minerals] is in the risk of having a profitable operation once you make a discovery. With oil and gas, once you drill a well or two and do geophysical work, you have a pretty good idea of the economics and you can expect to recover your capital investment over a period of years. With gold, you have much more capital at risk up front for a longer period of time, decades before you recover your capital investment, and you also have to take the risk of price fluctuations over that longer period of time.

Id. at 35 (statement of Dr. Sandra L. Blackstone, Consultant).

296 Id. ("The 1920 Mineral Leasing Act... was passed in 1920 after the United States had fought the great war in which oil powered ships and other vehicles played a vital role."); MAYER \& RILEY, supra note 51, at 169 (noting that withdrawals of oil land from the Mining Act by Taft "met the needs of a powerful official constituency, the American military"); Prince, supra note 63 , at 395 .

297 Clawson, supra note 171 , at 128.

298 MILLER, supra note 244, at 181.

299 Id. at 182. 
By the end of World War I, therefore, there were two powerful interest groups in favor of changing the Mining Law with respect to fuel minerals: the military and the oil industry. ${ }^{300}$ Westerners had reason to be alarmed-if those groups joined with other progressive or conservationist political groups, the Mining Law might be altered generally. Indeed, a general "demand for conservation of our natural resources" is one explanation offered for the 1920 leasing statute. ${ }^{301}$ Particularly since royalty or lease payments offered an attractive revenue source, those in favor of retaining the Mining Law could lose everything if the fuel minerals solution led to wholesale changes in the Mining Law. By agreeing to remove the fuel minerals, the hardrock interests could preserve the Mining Law's free access principle for hardrock minerals. This explanation fits the history of the Mineral Leasing Act's passage.

After World War I ended, a mineral leasing bill was introduced and handled by Utah Senator Reed Smoot, ${ }^{302}$ with unanimous support from both Democrats and Republicans from the West ${ }^{303}$ In the House, westerners again dominated the discussion of the bill. ${ }^{304}$ The debate featured overblown paeans to the Mining Law by westerners, with claims that it represented the "third great charter of democracy." ${ }^{\text {"05 }}$ Passage was quick and the Mineral Leasing Act of $1920^{306}$ removed fuel minerals from the Mining Law's coverage. One analysis of the Mineral Leasing Act notes:

The Mineral Leasing Act of 1920 represented a consensus among oil operators, large and small, among Westerners of all walks of life, among the administrations of Theodore Roosevelt, William Howard Taft, and Woodrow Wilson, and among the members of Congress of both parties. There can be no doubt that the conditions that formed such a consensus were a "crisis," not only for the oil industry, but for usage of federal lands. ${ }^{307}$

Westerners got to keep the elements of the Mining Law controlling hardrock minerals, the military got greater control over fuel supplies, and oil companies got new rules that increased the value of the resource, allowing them to share the gains with the government and still come out ahead. ${ }^{308}$

300 See MAYER \& RILEY, supra note 51, at 9 (noting that major oil companies favored withdrawal).

301 Davis, supra note 1, at 899.

302 Smoot was coauthor of the infamous Smoot-Hawley Tariff. MILLER, supra note 244, at 187. A credible case has been be made that this tariff played a key role in causing the Great Depression. See Richard N. Cooper, Trade Policy as Foreign Policy, in U.S. TRADE Policies IN A CHANGING WORLD ECONOMY 291, 291-92 (Robert M. Stern ed., 1987). That alone should make us skeptical of Senator Smoot's other legislative accomplishments.

303 MILLER, supra note 244, at 182-83.

304 Id. at 184 .

305 Id. at 185.

30630 U.S.C. $\S \S 181-193,195,201-209,211-214,223-229,241,251,261-263$ (2000).

307 MiLLER, supra note 244, at 186.

308 By creating a new interest group, federal lease holders, Congress lowered the costs for this group to seek benefits from Congress. Not surprisingly, lease holders did indeed seek these benefits. Congress regularly extended permits throughout the 1920 s and 1930 s, Davis, supra note 1 , at 908 , a straightforward transfer to existing permit holders. The new scheme also led to 
The fuel mineral story is thus a straightforward public choice tale: by exploiting a "crisis," interest groups secured changes in the law that rewarded them by restricting competition through expanding claim size, and bureaucracies sought expanded authority. Hardrock interests went along with the initial severance of fuel minerals both because it had little impact on them and because doing so protected their interests from a potential "bootleggers and Baptists" 309 alliance of the military, oil companies, progressive reformers, and conservationists that might have threatened the Mining Law generally.

The second set of minerals withdrawn were the "common variety minerals," taken out of the Mining Law in 1955..$^{310}$ These included sand, gravel, cinders, and similar materials. This new category was created without public hearings or any public controversy. ${ }^{311}$ Congress also simultaneously opened millions of acres of previously withdrawn lands to coverage. ${ }^{312}$

The common variety minerals presented the opposite problem from that created by oil and gas. Rather than being too expensive and difficult to locate compared to hardrock minerals, the common variety minerals were too easy to discover. Allowing claims based on the common variety minerals threatened to privatize significant amounts of the public domain in a short time. The rapid privatization of land outside Las Vegas, Nevada as it boomed in the 1950s, for example, led to withdrawals of land used for development. ${ }^{313}$ Such mass privatization would have hurt the federal land management agencies, which were threatened with the loss of large amounts of the property they managed. Grazing interests that held implicit property rights to much of the federal land in the west would have been harmed by such privatization. Again, the problems caused by claims on land containing these minerals threatened a more general "reform" of the Mining Law, in which the free access principle would be at risk. ${ }^{314}$ The withdrawal of the common variety minerals is thus best understood not as an efficiency move but as a protective measure by federal land managers and those with

increases in power for those who administered it: amendments in the 1930s increased Interior Department control over fuel leases. Id. ("The trend of the legislation of 1935 is to increase still further the bureaucratic control of the Department of the Interior over the oil lands and over all operations thereon.").

309 See Bruce Yandle, Bootleggers and Baptists: The Education of a Regulatory Economist, REG., May/June 1983, at 12, 13-14 (explaining the bootleggers and Baptists theory); see also Bruce Yandle \& Stuart Buck, Bootleggers, Baptists, And The Global Warming Battle, 26 HARv. ENVTL. L. REV. 177 (2002) (applying the bootleggers and Baptists theory to explain the global warming debate).

310 Congress initially provided for the sale of these minerals in 1947 , without addressing the availability of claims under the Mining Law for such minerals. LESHY, supra note 4, at 68-69.

311 MILLER, supra note 244, at 228 . This expansion of the "common variety" class drew praise from the Sierra Club, which endorsed it as "an outstanding conservation achievement of the 84th Congress." Id. at 229.

312 Id. at 228.

313 LESHY, supra note 4 , at 69.

314 Id. (noting the "reform efforts mounting" in 1955). 
existing implicit rights to federal land who were threatened by the ability of outsiders to gain control of property in a way that overrode their implicit rights. Therefore, the mineral withdrawal stories do not cast doubt on the Mining Law's appropriateness for hardrock minerals.

\section{Land Exclusions and Withdrawals}

In addition to withdrawing minerals from the Mining Law, Presidents and Congresses have periodically withdrawn parcels of land from the Mining Law's coverage. Most notably, land designated for park use (e.g., Yellowstone) and purchased lands are generally not included in the Mining Law (or other land disposal laws) ${ }^{315}$ The first major withdrawals were by President William Howard Taft in 1909, in an act done without express legislative authority ${ }^{316}$ and despite Taft's own doubts about his authority to take such an action unilaterally. ${ }^{317}$ Shortly thereafter, Congress granted the president authority to withdraw public lands from the Mining Law ${ }^{318}$ and extensive withdrawals were made under the new law. ${ }^{319}$ Such withdrawals continue in more recent times. During the Clinton Administration, for example, five million acres of public land were withdrawn from the Mining Law by executive order. ${ }^{320}$ Mining Law critic John Leshy argues that there has been a "consistent retreat by all branches of the federal government from the Mining Law's policy of free access" and that this retreat "speaks volumes" about the "continued viability" of free access. ${ }^{321}$ Leshy also argues that "[e]ach restriction on free access adopted over the years has in some way reflected a judgment about its merits as a policy." 322 Similarly Congressman Nick Joe Rahall II, a strong opponent of the Mining Law, has argued that land withdrawals show the need to replace the Mining Law. ${ }^{323}$ Do these withdrawals indicate that the Mining Law is obsolete?

315 Comm. ON INTERIor and INSUlar AFfaIrs, U.S. Senate, The Public Lands: Background INFORMATION ON THE OPERATION OF THE PRESENT PUBLIC LAND LAWS 3 (1963) ("[N]one of the 57 million acres of acquired lands are open to entry under the public land laws. Their legal status makes the land laws inapplicable and they usually have been acquired by the Federal Government for a specific purpose.").

316 Davis, supra note 1 , at 906 . The withdrawal was upheld by a divided court in United States v. Midwest Oil Co., 236 U.S. 459 (1915).

317 Colby, supra note 3, at 375 ("President Taft had expressed grave doubt as to his authority to make these extensive withdrawals of lands ... in the absence of congressional approval.").

318 Pickett Act of 1910, Pub. L. No. 61-303, 36 Stat. 847 (1910), repealed by Federal Land Policy and Management Act of 1976, Pub. L. No. 94-579, § 70-4(a), 90 Stat. 2743, 2792. For a thorough analysis of statutes authorizing withdrawals for preservation, see Mark Squillace, The Monumental Legacy of the Antiquities Act of 1906, 37 GA. L. REv. 473 (2003).

319 Pickett Act of 1910, 36 Stat. 847.

320 Ranchod, supra note 106, at 535; see also Leshy, supra note 97, at 480 ("During its eight years in office, the Clinton Administration continued the long-term trend of withdrawing more and more federal land from the operation of the Mining Law.").

321 LESHY, supra note 4, at 29.

322 Id. at 49.

323 Nick Joe Rahall II, The Mining Law of 1872, in THE MINING LAW of 1872: A LEGAL AND HISTORICAL ANALYSIS 9, 10 (1989). 
No. There are two sets of land withdrawals to consider. First, the federal government determines at times that particular parcels of land should be devoted to uses that preclude mining. Yellowstone National Park, for example, was created to prevent homestead and other claims in what is now the park. ${ }^{324}$ While we urge caution about federal land management decisions-whether to mine or to create a park-because of the incentive problems we described earlier, there is no systematic reason that withdrawals per se are inappropriate. Unless the goal was to fully privatize federal land holdings, ${ }^{325}$ withdrawal power is necessary once a dedicated use has been chosen for a particular piece of federal land. ${ }^{326}$

Moreover, Mining Law critics' reliance on these withdrawals suggests that executive and congressional actions withdrawing lands are presumptively socially beneficial. Leshy, for example, attributes withdrawals to "a different balancing of mineral values with the other values of these lands. ${ }^{327}$ This neglects the critical question of who is doing the balancing. Federal land management agencies suffer a loss when land is privatized; their preference for preventing privatization is unrelated to any social calculus weighing the relative benefits and costs of land use strategies. Congressional action to reverse executive withdrawals will almost inevitably fail because of the geographic concentration of mining interests in a few low population western states. Since withdrawals are effectively transfers from westerners to the rest of the country, even withdrawals that are extremely wasteful will still have majority support in Congress.

Over time, the withdrawal power has been used extensively. A 1975 analysis found over $\mathbf{4 0 0}$ million acres had been withdrawn from the Mining Law and over 500 million from the Mineral Leasing Act. ${ }^{328}$ The survey found that withdrawals were made in response to interest group pressures. ${ }^{329}$

324 Aubrey L. Haines, Nat'l Park Service, Yellowstone Nat'l Park: Its Exploration and ESTABLISHMENT 109-28 (1974) (describing the creation of the park and the role of Northern Pacific Railroad in lobbying for the park to prevent natural features from being privatized to preserve tourist revenue); LESHY, supra note 4, at 30-31 (discussing park withdrawals).

325 We leave to other work the question of whether this would be desirable.

326 For example, in 1976, Congress passed Pub. L. No. 94-429, 90 Stat. 1342 (1976), which withdrew land in six national parks from the Mining Law system. Unlike most national park land, where the land is withdrawn when the park is established, these six parks had continued to be subject to mining law coverage under the legislation establishing the parks. H.R. REP. No. 94-1428, at 4 (1976) ("These six areas were classified as open to mineral entry by specific legislation, generally at the time they were first authorized."). For example, the legislation establishing Death Valley National Monument did not bar mining activity in part to preserve "the picturesque figure of the prospector and his burro" in a place where "a significant aspect of the history... was the role of the prospector." Id. The introduction of modern mining technology, however, "altered this situation radically" and ended the rationale for allowing mining to continue. Id. Interestingly, even on an issue that might appear as uncontroversial as removing national parks and national monuments from mining claims, the House Interior Committee divided closely over one area, opting by a $22-19$ vote to continue to allow mining activity on a portion of Glacier Bay National Monument. Id. at 18-19.

327 LESHY, supra note 4 , at 29.

328 Gary Bennethum \& L. Courtland Lee, Is Our Account Overdrawn?, 61 MinING Congress J. 33,48 (1975).

329 Id. 
The second set of withdrawals is acquired federal land. Here the incentive analysis suggests important reasons not to allow mining claims. When the federal government buys land, it generally buys the full bundle of rights, including mineral rights. Under the Takings Clause, the government must pay market value for these rights if acquired from the original holder involuntarily. If acquired voluntarily, the land is by definition acquired at market rate. The price thus reflects the full value of the bundle of rights, including the mineral rights.

If such lands were open under the Mining Law to claims, the previous owner, who would be the most likely to have information on the value of the mineral rights, could simply return after selling the land and reclaim the mineral rights (and thus the surface estate). The federal land acquisition agent could also exploit her knowledge of the parcel to make a claim. The potential for corruption in such circumstances is enormous. In short, the reason the Mining Law does not apply to acquired lands is that the public paid for the land and the mineral rights and, assuming the land was bought for a legitimate public purpose, there is no reason to reprivatize those resources.

\section{State and Private Resources}

State governments' and private individuals' behavior with respect to their mineral resources present an important challenge for the Mining Law. No state has adopted the patent system for resources owned by the state, ${ }^{330}$ but no state has land holdings equivalent to the federal government's holdings either. Not surprisingly, mining operations on state lands are therefore less frequent than on federal land. ${ }^{331}$ Similarly, private landowners do not give away mineral resources found on their land, instead requiring those who wish to acquire them to contract for the right to do so ${ }^{332}$ If these landowners do not give away mineral rights, why should the federal government? ${ }^{333}$ Is there something distinctive about federal ownership that makes privatization particularly important with respect to federally owned mineral resources?

In a word, yes. The federal government is a monopoly landowner, whereas states are not. Competition amongst the states and with private landowners disciplines states, but it does not discipline the federal government because the federal government has such enormously

330 Prince, supra note 63 , at 395 ("[N]o state has adopted the federal mining law system of giving the discoverer a right to patent a claim.").

3311990 Senate Hearings, supra note 4, at 150 (statement of Mr. Stephen D. Alfers, Attorney) (witness testifying that "[i]n [his] experience, it has been the exception to find an operation being opened on State lands.").

332 Prince, supra note 63, at 396 ("Mineral leases are probably the most common method of acquiring mineral rights in privately-owned minerals.")

333 See LESHY, supra note 4, at 334 ("Perhaps the most telling [argument in favor of leasing] is that leasing systems have been used for hardrock mineral activities on millions of acres of federal, state, and private land in the United States."). 
concentrated land holdings. ${ }^{334}$ Lessees will thus face a monopoly seller if the federal government is allowed to sell mineral resources. Monopolists generally price above the competitive price, something the Congressional Research Service recognized the government could do in a study of royalty issues. ${ }^{335}$ Moreover, there are important incentive problems for federal land managers that are more serious than those faced by state land managers. ${ }^{336}$ Privatization may thus be an appropriate strategy for the former but not the latter. It may also be appropriate for both, of course, but our concern here is simply whether states' failure to follow privatization strategies like the Mining Law suggest that the federal government should not do so, and not whether the Mining Law's success suggests that states should mimic the federal government. It does not.

\section{E. Summary}

We have tested our analysis of the Mining Law against four potential objections. We conclude that the withdrawal of particular minerals and lands from the Mining Law's coverage is best explained by the circumstances surrounding those minerals and lands, and not by any overall weakness in the Mining Law's incentive structure. The end of other land disposal laws developed in the same era as the Mining Law also does not support repealing the Mining Law. The homestead laws suffered from structural problems not present in mining. Those problems justified the repeal of those laws, not a general dissatisfaction with private ownership of land. Finally, the behavior of state and private mineral resource owners is not a model for federal land management because there are differences in the incentives for monopolists and those subject to competitive pressures.

\section{CONCLUSION}

The story we have told about the General Mining Law of 1872 is quite different from the story usually told by the law's critics. It also differs from the story usually told by the law's defenders. We do not argue that the Mining Law deserves to be continued because of the need to boost mineral production, to provide jobs in western states, or safeguard strategic national interests. ${ }^{337}$ Instead we contend that the Mining Law is the result of a

${ }^{334}$ Idaho Senator McClure articulated this point at the 1990 Senate Hearings. " $[\mathrm{I}] \mathrm{n}$ the State of Idaho, the Federal Government is not just like any other landowner. It owns two-thirds of my state. I resent it bitterly. I wish to hell [it] didn't." 1990 Senate Hearings, supra note 4, at 153.

335 Memorandum from the Economics Division of the Congressional Research Service to the Senate Committee on Energy and Natural Resources 5 (Sept. 8, 1990), reprinted in 1990 Senate Hearings, supra note 4, at 290, 294 ("Moreover, as a large landowner, the Federal Government is in a position to exert monopoly power in the factor market if it wanted to, in order to extract higher royalty rates.").

336 See LEAL, supra note 156, at para. 63 (attributing superior performance of state land managers over federal land managers in part to the existence of residual claimants entitled to revenue from land management, such as school districts).

337 See, e.g., Miscellaneous Forest and Land Bills: Hearing on S. 439, S. 719, S. 930, S. 1030, S. 1288, and S. 1374 Before the Subcomm. on Forests and Pub. Land Mgmt. of the Senate Comm. 
political process that unintentionally produced a law that solves the most important problem of federal land ownership, at least with respect to the subsurface estate. It effectively privatizes land while avoiding many of the pitfalls that have plagued other privatization efforts.

The 1912 House hearings on homestead law reform included a exchange between Wyoming Congressman Frank Mondell and Secretary of the Interior Walter L. Fisher that captures the essence of our argument. Fisher first proposed classifying federal lands by use, retaining forest land suitable only for forestry as public and allowing homesteading only on land suited for agriculture. Mondell asked Fisher if the retained lands would include "the rough, broken, and generally rocky divides and hills that extend through the intermountain States between the valleys" and similar land. Their conversation continued:

Secretary Fisher: "I think so. Why not?"

Mondell: "It occurred to me the Government would have a pretty large contract if it took over every rocky divide in a State like mine."

Secretary Fisher: "Why shouldn't it?"

Mondell: "Why should it?"338

This exchange captures the essence of the real debate over the Mining Law, and goes beyond those who are simply opposed to mining and seek to use any means to stop it. The Mining Law asks, why keep property in the federal domain? The critics of the Mining Law ask, why privatize? It may be that we have come to the point at which the modern critics' question is the right one-but if we have, these critics must articulate solutions to the problems the Mining Law solves. The benefit of the Mining Law's approach, as unintentional as it might have been, is that it creates a set of private owners of the mineral resources. These resource owners may receive the benefit of the surface estate as well, thus ensuring that they consider the benefits of alternative uses and take steps to preserve and enhance environmental amenities on the land. The corrupting effect of mineral deposits, so visible around the world, is avoided. Far from a wasteful giveaway of public resources, the Mining Law is an effective means of creating incentives for careful stewardship of both land and mineral resources.

In a recent paper attacking the natural resource curse hypothesis, ${ }^{339}$ economists Gavin Wright and Jesse Czelusta argued that

on Energy and Natural Res., 106th Cong. 4-5 (1999) (statement of Senator Harry Reid) (justifying the Mining Law based on economic impact); Miscellaneous Mining Bills: Hearing on S. 326, S. 327, and S. 1102 Before the Subcomm. on Forests and Pub. Land Mgmt. of the Senate Comm. on Energy and Natural Res., 105th Cong. 2 (1998) (statement of Senator Frank Murkowski) ("We've got jobs. We've got U.S. production of feedstocks for the Nation's mills and factories."); T.H. Watkins, Hard Rock Legacy, NAT'L GEOGRAPHIC, Mar. 2000, at 76, 81 (noting that supporters of law credit it with $\$ 7.7$ billion in local economic impact and 84,000 jobs in the West from gold and silver alone).

3381912 House Hearings, supra note 191 , at 16.

339 The hypothesis is that countries with natural resources have poor prospects for development. 
[m]inerals themselves are not to blame for problems of rent-seeking and corruption. Instead, it is largely the manner in which policy makers and businesses view minerals that determines the outcome. If minerals are conceived as fixed stocks, and mineral abundance as a 'windfall' unconnected to past investment, then the problem becomes one of divvying up the bounty rather than creating more bounty. ${ }^{340}$

The success of the Mineral Law is that it prevents such a mindset from developing.

The Mining Law has persisted because its strengths outweigh its weaknesses. There is no question, as Mining Law critic John Leshy notes, that the Mining Law could be improved within the free access framework by removing some of the overly complex, dysfunctional aspects such as the lode-placer distinction. ${ }^{341}$ Preserving free access is worth the costs those complications impose, however. By awarding secure mineral rights based on investment in knowledge about the existence of mineral resources, the Mining Law encourages the creation of more bounty and the responsible stewardship of the resources. The continuation of the Mining Law despite its flaws is a testament to the high value it provides through the self-initiated, free access principle. ${ }^{342}$

The free access principle provides an effective tool to privatize assets whose value is unknown but can be learned through investment in knowledge. Since mineral economies today are dominated by efforts to privatize ${ }^{343}$ this is a valuable model. By privatizing such assets in response to the creation of knowledge, the free access principle encourages investment in knowledge. By creating residual claimants for the resources, it encourages appropriate decisions about the resources' disposition and resolves conflicts over multiple uses. By removing discretionary decisions from government officials, the free access principle reduces both the supply of and demand for corruption. Far from an anachronism, the General Mining Law of 1872 is a model for a new century.

340 Gavin Wright \& Jesse Czelusta, Mineral Resources and Economic Development 26 (2003) (unpublished manuscript) (on file with authors).

341 LESHY, supra note 4 , at 347.

342 Removing the transaction-cost-increasing aspects of the law would be better than the status quo, but the danger of opening the free access principle to attack from its many opponents has prevented such actions. See Parr, supra note 133, at 70 (" "T) he law still meets the basic needs of the industry to explore for, investigate, and develop mineral deposits on federal lands because of the availability of self-initiated rights."). In our next article on the Mining Law, we will address the history of "reform" efforts through a public choice perspective.

343 OTTO \& CORDES, supra note 48 , at 1-50 ("Perhaps the most dramatic change [recently] is reflected in the effort of mineral economies to privatize mining investments."). 
*** 